\title{
Verification and Validation: A Novel Product Lifecycle Management-based Approach
}

\author{
Aineias Karkasinas ${ }^{1}$ and Athanasios Rentizelas ${ }^{2}$ \\ ${ }^{1,2}$ Department of Design, Manufacturing and Engineering Management \\ Strathclyde University \\ 75 Montrose St, Glasgow G1 1XJ \\ 1aineias.karkasinas@strath.ac.uk, ${ }^{2}$ athanasios.rentizelas@strath.ac.uk
}

\begin{abstract}
This work sets out to provide clarity on the current use of Verification and Validation (V\&V) practices across the product's lifecycle and proposes a novel product lifecycle managementbased V\&V approach. By systematically analysing the literature, stages, scope, methods and techniques used for $\mathrm{V} \& \mathrm{~V}$ were investigated, leading to classification and clustering of the $\mathrm{V} \& \mathrm{~V}$ methods or techniques from the product's lifecycle perspective. The analysis revealed that $V \& V$ are not currently addressed as lifecycle processes, they are largely absent from the post-production phases and provided insights on how V\&V can be applied across the product's lifecycle by proposing a novel Product Lifecycle Management-based (PLM) approach for $\mathrm{V} \& \mathrm{~V}$. This paper is the first to map the 'as is' $\mathrm{V} \& \mathrm{~V}$ practices across the product's lifecycle and supports the engineers and academics on how V\&V processes can be applied beyond the internal organizational boundaries by developing a PLM based approach for V\&V.
\end{abstract}

Keywords: Design validation, Process validation, Product verification, Design verification, Product Lifecycle Management, PLM, Systematic Literature Review

Paper Type: Literature Review

\section{Introduction}

Modern manufacturing is struggling to cope with globalisation, product customisation and the continuously decreasing time to market (Maropoulos and Ceglarek, 2010; Filippi and Barattin, 2016). Practices that promote the 'make it correct the first time' approach are becoming increasingly important, especially in product design, which can be an extremely timeconsuming process (Jung et al., 2015). Processes such as Verification and Validation (V\&V) can guarantee conformity to the product's design specifications and provide guidelines for the manufacturing process.

$\mathrm{V} \& \mathrm{~V}$ are key processes since $80 \%$ of product's total manufacturing cost is locked in at the conceptual design phase (Kim et al., 2015) and both V\&V are related with the appraisal costs (Aleem et al., 2003). Multiple economic benefits from effective V\&V can be realized from reduction of the appraisal costs (VDI, 2002), decrease of the product design costs (Hazra et al., 
2012), improved product performance and reliability (Jung et al., 2015), identification of design flaws at an early stage (Zhou et al., 2015), decrease of the rework of a product and promotion of the most suitable Quality Management strategy (Aleem et al., 2003).

Challenges regarding the $\mathrm{V} \& \mathrm{~V}$ manufacturing processes may be related to the vagueness of those two terms (Duren, 2006), duplication of related tasks (Aleem et al., 2003), vast amount of paperwork (Aleem et al., 2003), inadequate studies for measuring the impact of those processes in industries (Aleem et al., 2003) and complexity in product design (Maropoulos and Ceglarek, 2010).

Analysis of the most common and widely used definitions for $V \& V$ led the researchers to identify that the main differences between those definitions originate from the domain of implementation. Thus, multiple studies and organisations have defined V\&V primarily focusing on the digital domain (Balci and Sargent, 1981; American Institute of Aeronautics and Astronautics., 1998; FDA, 2002; Babuska and Tinsley, 2004; US Department of the Navy (DON), 2004; Allen, Shaffer and Watson, 2005; ISO, 2005; Schwer, 2007), while others focused mainly on the physical domain (Goldsmith, 2010; Joint Committee For Guides In Metrology, 2012).

There are many defitions used for Verification and Validation. In simple terms, validation can be expressed by the query "Are you building the right thing?" and verification by "Are you building it right?"'. This study adopts the following formal definitions: 'Verification: confirmation, through the provision of objective evidence, that specified requirements have been fulfilled' and, 'Validation: confirmation, through the provision of objective evidence, that the requirements for specific intended use or application have been fulfilled' (ISO, 2005). Those definitions were selected because they are generic enough to describe the wide spectrum of $\mathrm{V} \& \mathrm{~V}$ practices and products to both domains. The main difference between the two definitions is that Verification focuses on whether the product's characteristics have met the designer's expectations and, Validation on whether the design of the product itself has met the consumers' expectations. By accurately defining $V \& V$, it becomes easier to study the impact of those two processes.

Previous studies have underpinned the need for extending the V\&V across the product lifecycle stages with the scope of achieving increased confidence in systems (Sibois et al., 2014) while other studies focused more on extending V\&V beyond the organisational boundaries by integrating independent divisions or companies in order to involve the end user in those processes (Bahill and Henderson, 2005). Some researchers identify validation as a process that is performed and finalized at the manufacturing stage and claim that design validation techniques are an attempt to establish a fruitful relationship between the correctness of the design and the implementation of the manufacturing processes (Krishnamurthy et al., 2000). On the other hand, other researchers and organisations followed a different approach by claiming that validation is a lifecycle process that must be performed across the multiple product's lifecycle stages (Aleem et al., 2003). The 2011 Guidance from the US Food and Drugs Administration (FDA), adopted this lifecycle approach by promoting validation as a process visible across the stages of the life of the product (Campbell, 2014). Therefore, there 
seems to be no consensus on the extent of the Product Lifecycle Management (PLM) stages $\mathrm{V} \& \mathrm{~V}$ processes should be applied.

Studies have shown that better understanding of $V \& V$ methods, its steps and process integration of $\mathrm{V} \& \mathrm{~V}$ with a lifecycle strategy can achieve measurable impact and improvements in reducing product defects and rework ultimately reducing the costs of quality, product development and changes (VDI, 2002; Aleem et al., 2003). The impact stems from the clear $\mathrm{V} \& \mathrm{~V}$ practices which define the quality processes related to the product and stipulate the guiding lines for effective Quality Management in integration with the PLM. However, academia currently mostly studies validation and verification as pre-manufacturing, internal processes, covering a limited range of lifecycle stages across the PLM. This study sets the foundations for addressing $\mathrm{V} \& \mathrm{~V}$ as lifecycle processes and provides guidance on how V\&V processes can be applied beyond the internal organizational boundaries.

This paper will answer the following Research Question (RQ): 'How Verification and Validation can be implemented across the product's lifecycle?'. To achieve this, this paper aims firstly to map the 'as-is' situation of the V\&V practices by identifying the most common methods used for implementing $\mathrm{V} \& \mathrm{~V}$ in the literature and through analysis of the results, to classify them across the lifecycle stages of the product. Moreover, this paper aims to provide crucial information and guidance to the practitioners regarding how V\&V can be implemented across the lifecycle stages. Finally, since this paper's methodology is based on a literature review, it aims to identify gaps and provide suggestions for future studies. Thus, this work aims to be used as a stepping stone for companies, especially those with limited resources such as SMEs, to successfully develop affordable and well established V\&V strategies across their PLM, in contrast to the unstructured practices of the past (Sauza Bedolla et al., 2013).

The rest of the paper is organized as follows: Section 2 describes the adopted methodology for this Systematic Literature Review (SLR). Section 3 describes the adopted stages of the lifecycle approach and what is the main goal for V\&V per stage and, section 4 refers to the results of the analysis of the selected articles. Section 5 contains the discussion emerging from the answer to the Research Question. Moreover, it identifies gaps, describes the main outcomes from the qualitative and quantitative analysis of the articles, includes the limitations of this study, and suggests guidelines for future work. Finally, section 6 contains the conclusions of the study.

\section{Methodological Approach}

This chapter discusses the methodological approach followed by the researchers.

\subsection{Methodology and Databases of use}

In this study, a systematic approach was adopted to address the research question. A systematic review is 'a research article that identifies relevant studies, appraises their quality and summarises their results using scientific methodology' (Kahn et al., 2003). Systematic literature reviews are widely accepted in the research community since they ensure transparency and traceability of their results by offering high repeatability of the research (Tranfield et al., 2003). The process this study followed is presented in the flowchart depicted 
in Figure 1 and analysed in detail below, is an adaptation of well-established methods for systematic literature reviews (Jesson et al, 2011) with the main difference that inclusion and exclusion criteria were applied in multiple steps in order to achieve high relevance of the results with the scope of this research. The fact that both researchers applied the criteria on each stage independently promoted robustness and integrity for this study.

Figure 1: Flowchart of the SLR, based on Jesson et al. (2011)

\section{Flowchart of the Systematic Literature Review}

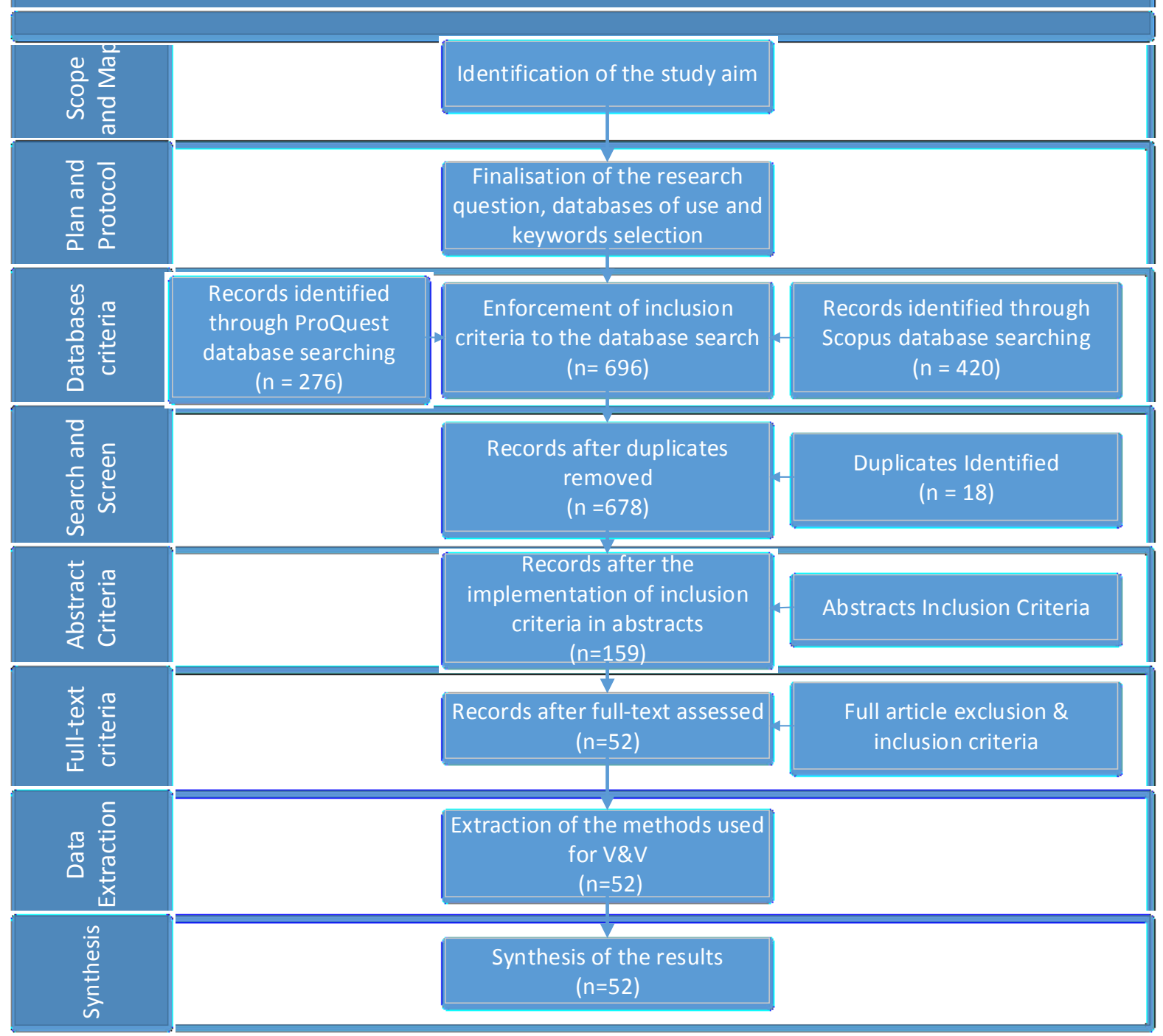

The selected databases were Scopus and ProQuest. Scopus was selected because it is the largest peer-reviewed journal database in engineering fields (Ahi and Searcy, 2013) and ProQuest because of its variety in content. Other factors were the high standards of quality for both databases and the wide spectrum of areas covered by the journals being hosted.

127 The main inclusion criteria applied in this initial database search step were:

- Only peer-reviewed journal articles are a part of this literature review for ensuring quality of the results 
- Only articles in the sub-categories of Engineering, Decision Making, Materials Science and Business and Management are a part of the research. As the two databases did not have common scientific area identification, the two researchers jointly mapped the matching categories between the two databases.

- Only articles written in the English language are a part of this review

2.2 Keywords Selection
The keywords that have been utilised for this research are: 'Design validation', 'Process validation', 'System Validation', 'Product verification' and 'Design verification' (Group 1). Selection of the Group 1 keywords was based on an iterative process of refining based on quality and relevance of results. The reason that two words are in quotes is that when verification or validation are searched as terms among published studies without a complimentary word, the outputs usually refer to the conformance of a computational or simulation model, which is beyond the scope of this work.

Additional to Group 1, for ensuring the relevance of the results the researchers used the following strings: 'Techniq*', 'frame*', 'Meth*' (Group 2). The rationale behind the selection of these three words is that from past studies in the fields of verification and validation, the words 'technique', 'method' or 'methodology' and 'framework' are most commonly used to describe ways of implementation for V\&V. Figure 2 contains the keywords selection:

Figure 2: Verification and Validation process and methodological elements

Group 1

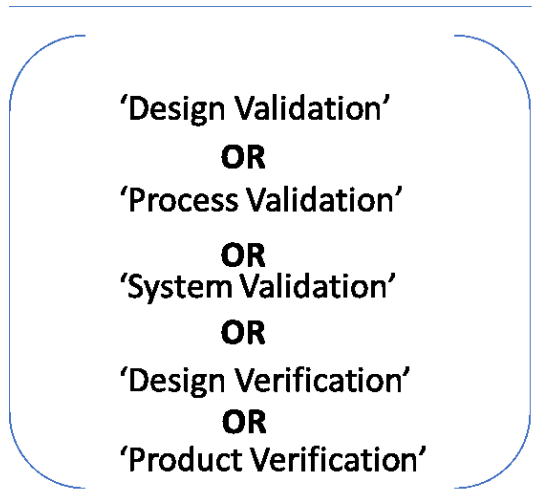

Group 2

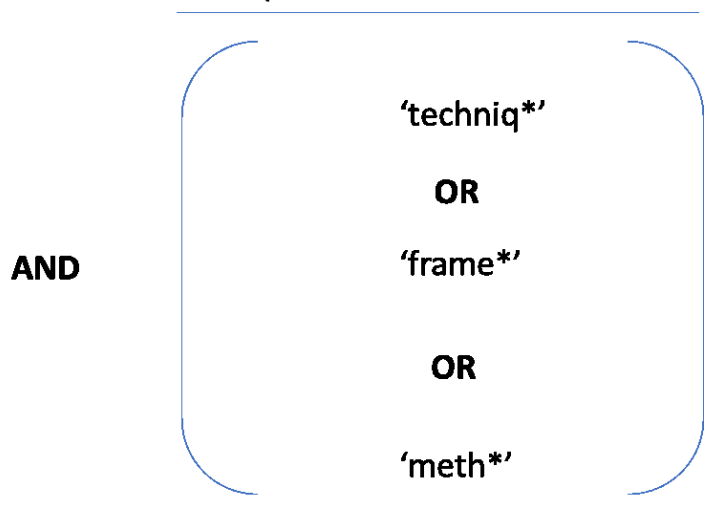

\subsection{Inclusion and Exclusion Criteria}

In order to review the abstracts of the articles and select the most pertinent with the scope of this research, the following inclusion criteria were applied to the abstracts of the 678 articles, as is depicted in Figure 2. Those were:

- The paper must provide a method for validation OR

- The paper must provide a method for verification

After the application of those criteria to the abstracts of the articles, the paper count dropped to 159. The final exclusion criteria were applied to the full text of each publication, excluding the following: 
- Case studies or applications with an extremely specific area of application and limited potential for generalisation

- Articles providing a method for $\mathrm{V} \& \mathrm{~V}$ of a simulation model. Those articles do not align with the scope of this study, which is not to identify methods of validating simulation models but to identify methods used for Verification and Validation.

- Articles focused on testing methods. Although it is quite common in studies for Verification and Validation to be accompanied by the use of testing methods (VV\&T) (Santini-Bell et al., 2008), those are distinct terms with different processes and outcomes. Testing is the most potent tool for achieving verification and validating a model/design. However, it is only a tool, while adopting a method for obtaining data and applying rigorous testing does not necessarily entail effective and successful V\&V plan and implementation.

Application of the above criteria resulted in the final sample of $\mathbf{5 2}$ articles, which are the cornerstones of this paper.

\section{Product Lifecycle Stages}

The classification of the V\&V methods to the different stages of the product's lifecycle demands an unambiguous identification of those stages. Multiple definitions of what is Product Lifecycle Management and what are its stages exist in the literature. Some differences can be identified among them; however, common ground has been established. An industry-focused definition of Product Lifecycle Management has been developed by CIMdata (CIMdata, 2020), identifies the key aspects of PLM in the following captions :

'A strategic business approach that applies a consistent set of business solutions that support the collaborative creation, management, dissemination, and use of product definition information'

\section{'Supporting the extended enterprise (customers, design and supply partners, etc.)'}

\section{'Spanning from concept to end of life of a product or plant'}

\section{'Integrating people, processes, business systems, and information'}

Figure 3 depicts the stages described in the literature by different authors and varying perspectives. In some studies, the weight was put on the stages up to the manufacturing of the product (Abramovici, O. Sieg, 2002b; PTC, 2008) while other authors tried to include more of the lifecycle stages (Stark, 2005; Liu et al., 2009; Ramani et al., 2010). The main difference between these two approaches is that by creating multiple and well-defined stages aimed at the design phase of the product, the theory of 'frontloading' is promoted by which issues might be identified and avoided in advance. This practice has been identified as a future trend of PLM (Maropoulos and Ceglarek, 2010). 


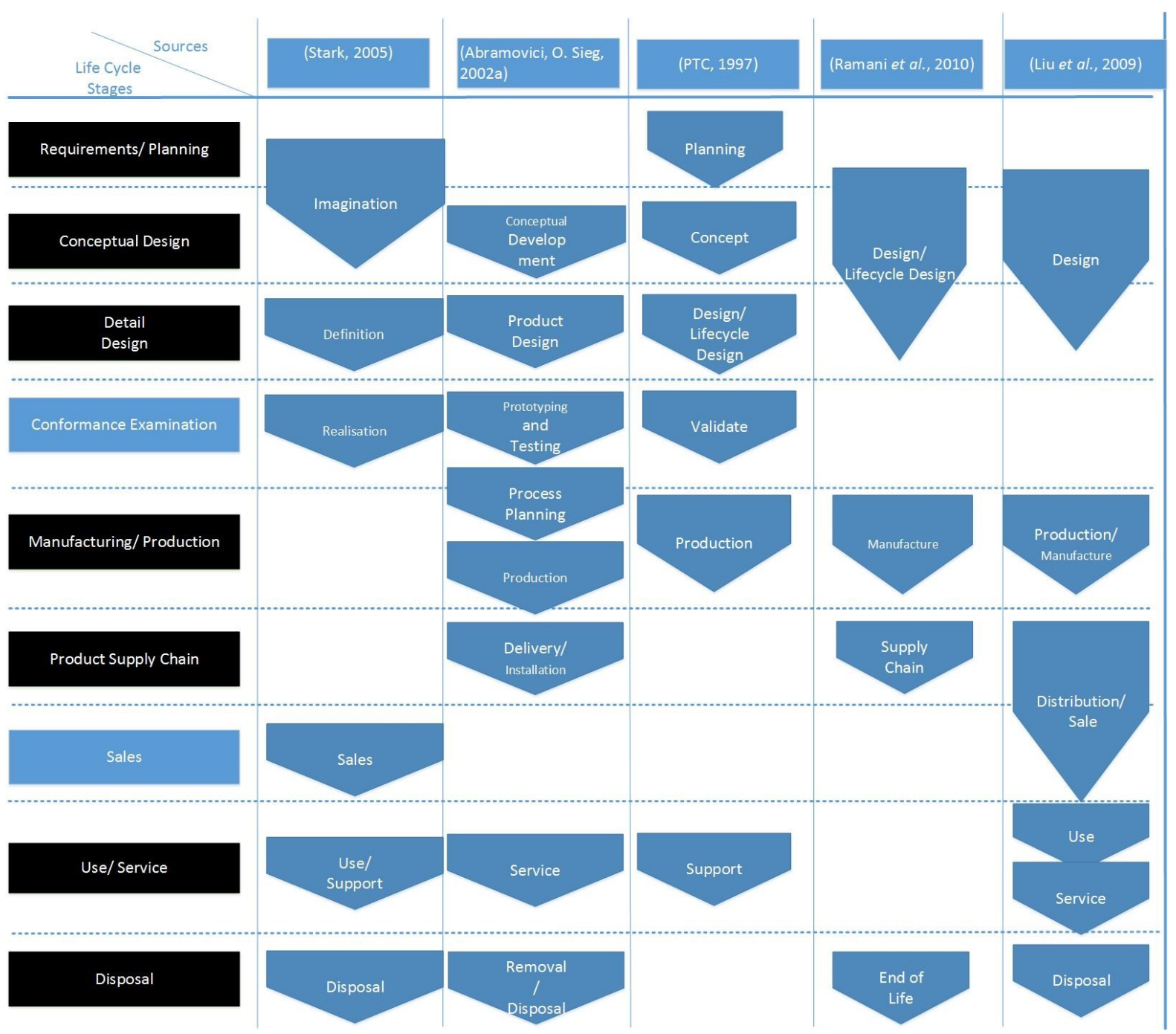

Figure 3 illustrates the main stages of the product's lifecycle that have been selected by the authors, coloured in black under the 'Life stages' column. These are the stages that the further analysis of the V\&V methods will be based on. Those stages will provide the ground for the methods to be classified and will depict the lifecycle limitations on the implementation of each method. Thus, it was crucial that those stages were thoroughly defined before proceeding in further analysis.

Taking those approaches into consideration, this paper created a chain of Lifecycle Stages, illustrated in the first column of Figure 3, which are in alignment with the ones proposed by the literature and with the trend of defining V\&V processes as lifecycle processes with direct or indirect impact on the whole spectrum of the product's phases. Some key points on the selection of the life stages are:

1) Several V\&V methods are focused on the correctness of capturing the customers/ consumers voice. The process of requirements turning into specifications is crucial for the development of a product and for establishing the guidelines for successful verification. This is the reason the researchers have kept the stage of 'Planning' as the 
first stage but renamed it to Requirements/Planning, which depict the aims of this stage.

2) The next stage of Conceptual Design is the first attempt of actually putting all the specifications together in the newly designed product and study their correctness and dynamic.

3) Detail design is the outcome of multiple departments' collaboration. It captures the information from the design team, the production, the quality, the marketing and the sales. It is the most crucial stage in which the design of the product is finalised and traditionally, this is the stage where the Validation Master Plan (VMP) is created. The VMP contains a detailed description of the V\&V processes, the stage that they will be implemented and who is responsible for each activity (Sherman, 2015).

4) The researchers do not adopt a specific 'Validation' or 'Testing' or 'Realisation' life stage as other previous studies (Abramovici, O. Sieg, 2002a; Stark, 2005; PTC, 2008). This adoption would come in contradiction with the scope of this study to address and analyse $\mathrm{V} \& \mathrm{~V}$ as lifecycle processes.

5) Manufacturing is the stage where the product is being manufactured. It is vital for the manufacturing process to meet the criteria that are set by the product's designers. Testing and robust quality policy is essential for high standard products, and the main testing processes take place during the production stage.

6) Supply Chain stage covers the logistics, distribution and delivery of the product. Keeping the quality in the same level for all the links of the supply chain is a constant goal of an efficient supply chain.

7) Service is the stage where support is provided to the consumer regarding the product. It is a stage that can provide real-life data emerging from the product's use. This data can be used as feedback for prior stages of other/similar designs for successful V\&V of the product.

8) The final stage selected is the Disposal. Eco-friendly materials, recycling, regulations, standards and legislation, sustainable solutions must be able to align with the disposal phase of the product, and the manufacturer must have taken into consideration those variables and verify that the correct processes are followed until the end of the product's lifecycle.

This study does not adopt the stage of 'Sales', as during this phase, the product is stationary, and no it does not undergo any change in its characteristics from the manufacturing and the quality management perspective. Moreover, the distribution of the product is already considered in the Supply Chain stage.

\section{Results}

This chapter presents the results of the SLR in both a quantitative and qualitative manner. Firstly, a bibliometric analysis provides an understanding of the evolution of the specific field. The next stage is the definition of the aims of $V \& V$ per life stage. Then follows the clustering of the V\&V methods and lastly, the classification of the publications leads to an analysis of the V\&V literature for each of the PLM stages. 


\subsection{Bibliometric Analysis}

The descriptive analysis of the 52 articles, presented in Figure 4, includes the distribution of the publications across the time spectrum. This research was conducted on peer-reviewed articles published form the year 1990 to the year 2017. It is evident that Verification and Validation have gained academic interest in the last ten years. The chart indicates a steep increase in research which peaked during 2010 with 12 published papers. The following years, except 2011, multiple papers were published, demonstrating a high academic interest for the V\&V practises.

Figure 4: Chronological distribution of selected papers

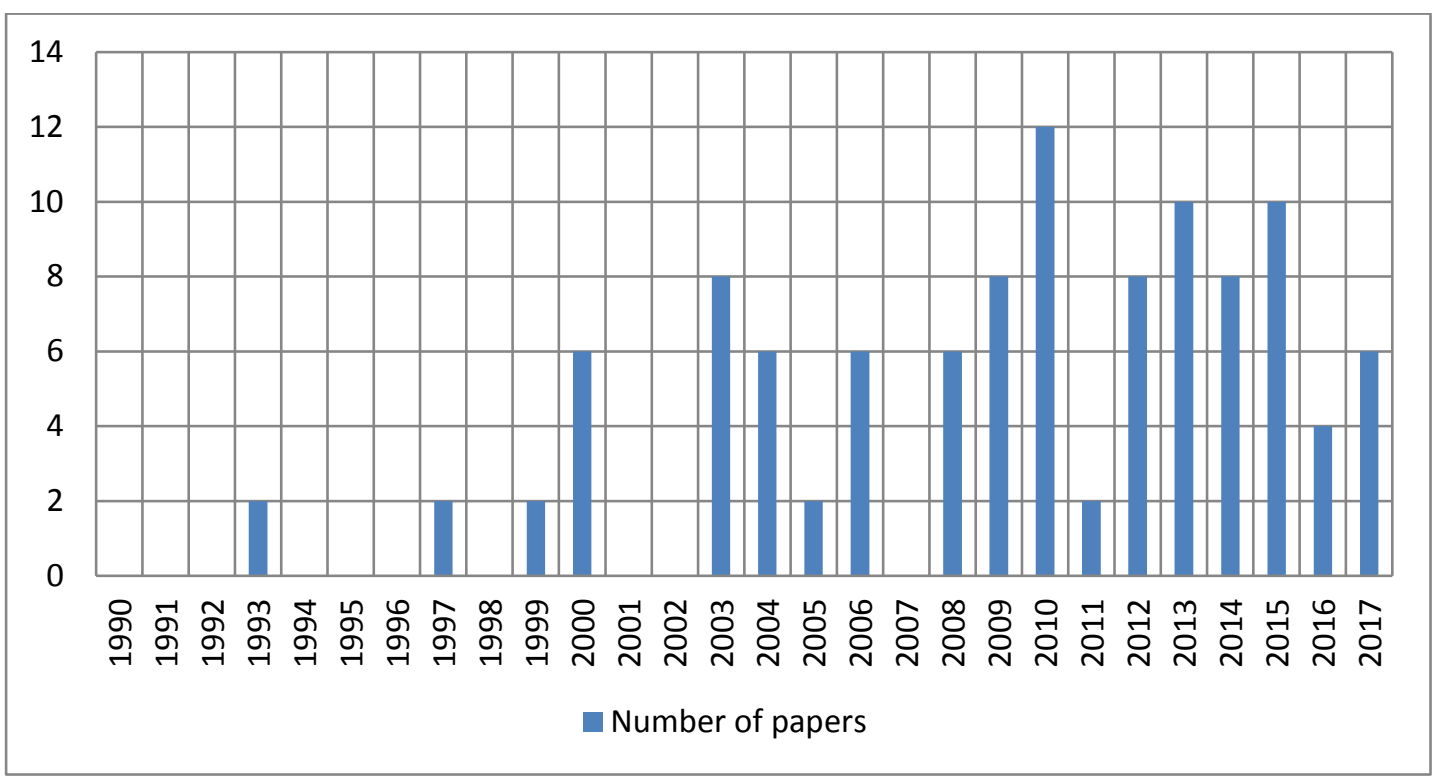

The researchers identified the journals' area of focus of the selected articles, with three of them being dominant: a) Software/ hardware, b) Aerospace and, c) Manufacturing \& Production. These groups combined contained 23 publications from a total of 52 articles. The rest of the papers were scattered among various journals with topics such as Health, Biomechanical, Quality and Business Management and other related fields.

\subsection{V\&V in the Product Lifecycle Stages}

Verification and validation are processes whose subject changes depending on the lifecycle stage they are applied to. Figure 5 presents a summary of the areas of focus per lifecyle stage based on the literature. Additionaly, the authors conducted an analysis on what the main V\&V processes are per stage. 


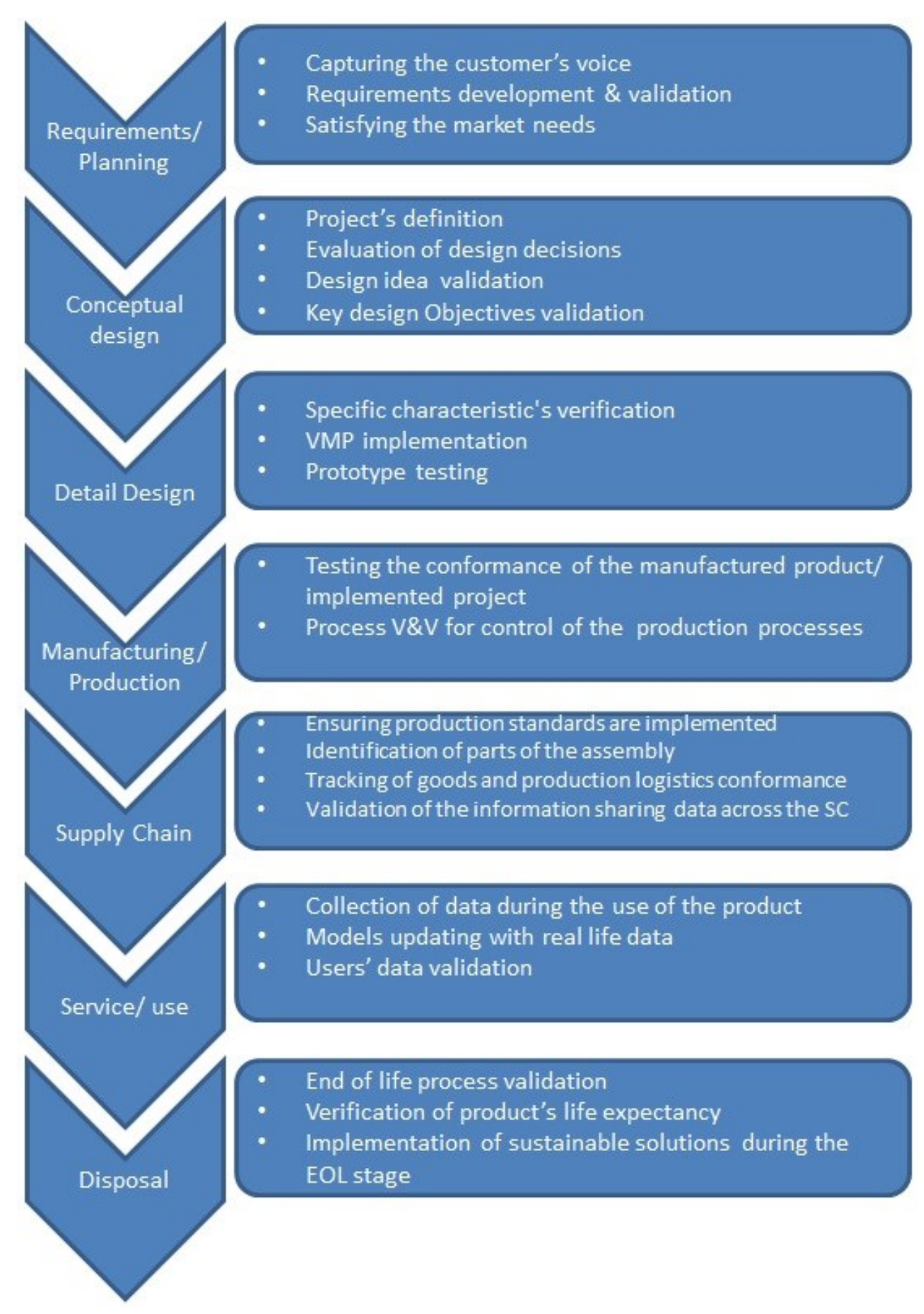

278 Requirements/ Planning: For the requirements/ planning stage, V\&V focuses on validating 279 the correctness of the product's requirements that have been selected for future development. 280 It includes methods aimed to capture the customer's voice such as QFD or TRIZ, which aim at 281 designing the ideal product (Pignataro, Lobaccaro and Zani, 2014), as well as the technical and 282 lifecycle requirements arising from understanding and interpreting market needs (Maropoulos and Ceglarek, 2010). Researchers have identified that Requirements Validation proves that the requirements (and hence the system design) should satisfy the customer's need or purpose before the system is actually built (Duren, 2006). 
Conceptual Design: Studies have claimed that a well thought V\&V plan can guide the testing processes during a project's definition stage(Duren, 2006). V\&V in the conceptual design, also known as V\&V in the early stages, can achieve early stage verification of the design (Sibois et $a l ., 2014)$ by studying all the initial decisions of one or multiple designs and evaluating their correctness. Thus, the optimum alternative can be selected. Main subject of V\&V during this stage is the outline of methods for design idea validation as well as more technical aspects such as ensuring the consistency in key design objectives and the Key Characteristics (KCs) (Maropoulos and Ceglarek, 2010).

Detail Design: V\&V during the detail design includes verification of specific characteristics, such as the Key Control Characteristics (KCCs) and describes in great detail how those characteristics should be monitored. Additionally, it contains validation of the product's design and extensive testing of the prototype, physical or digital. All the information of how V\&V should be applied is part of the Validation Master Plan (VMP) which is conducted by the engineers. Since the main subject of $V \& V$ at this stage is validation of the product's design and verification of the Key Control Characteristics (KCCs), this is the main stage of implementation of $\mathrm{V} \& \mathrm{~V}$ adopting various approaches. For instance, some researchers used mathematical approaches to achieve validation (Duren, 2006; Cambronero, Valero and Díaz, 2010; Balachandran, Ozay and Atkins, 2016) while others focused on providing validation of the detail design through the digital domain (Aleem et al., 2003; Ferrise, Bordegoni and Graziosi, 2013) and/or physical prototyping (Lan, Arteau and Sirard, 2004). Prototyping includes physical, digital and virtual techniques. The methods used for prototyping consist the $9.17 \%$ of all the methods identified for $\mathrm{V} \& \mathrm{~V}$ in this study and most of them refer to digital methods with main goal to provide early design $\mathrm{V} \& \mathrm{~V}$.

Manufacturing/ Production: The subject of V\&V during the manufacturing or production is inextricably linked with testing and can be expressed through examination of product's characteristics' conformance such as tolerances, geometric characteristics etc. At this stage Metrology is a powerful tool for achieving V\&V and the engineers apply the VMP that had been developed in the previous stages. Some researchers followed this direct approach on examining the manufactured goods and testing them for V\&V purposes (Aleem et al., 2003; Weissman, Petrov and Gupta, 2011; Pignataro, Lobaccaro and Zani, 2014) while others achieved V\&V indirectly, by controlling and verifying the processes related to manufacturing (Hammett, Wahl and Baron, 1999; Chin, Zheng and Wei, 2003).

Product Supply Chain: V\&V practices span beyond the internal organisational boundaries, are well spread across the Supply Chain and are usually expressed through Standards, Identification and Tracking. Previous studies have claimed that the subject of V\&V should be the standardisation of manufacturing execution protocols for establishing an unambiguous definition "language" throughout a global supply chain and ensure consistent product performance in the service phase (Maropoulos and Ceglarek, 2010). Other researchers focused on verification of the production schedules and logistics achieved with the use of tracking methods such as RFID (Huang, Wright and Newman, 2011) (Huang, Wright and Newman, 2011) while other studies pointed out that validation practitioners cannot complete the validation processes without assessing suppliers and having a deep understanding of which 
tests were conducted on the supplier's side (Wakabayashi et al., 2017). From the V\&V clusters, testing focuses on providing alignment with standards set by the OEM on the post-production phases and is the most common practice for examining the supplier's quality during the commissioning.

Use/ Service: V\&V across the use or service life stage focuses on capturing data related to the use of the product and its performance for design analysis or model's updating. Some studies aim at providing methods of how this data can be validated for direct use (Wakabayashi et al., 2017) while others used non-destructive testing to obtain data from infrastructures for design verification (Santini-Bell et al., 2008).

Disposal: The subject of $V \& V$ in the disposal phase is linked with the data related to how the product should be disposed, its life expectancy and its condition. This study concludes that at the end of the lifecycle $V \& V$ is not performed. The rising of more sustainable practices, such as remanufacturing, circular economy and others, requires that data related to the end of lifecycle of the product should be taken into consideration and feed the initial design process in an attempt to optimise the product's design.

\subsection{Clusters of the V\&V Methods}

$\mathrm{V} \& \mathrm{~V}$ methods and techniques were studied through the product's lifecycle perspective. The methods identified were classified into 20 different clusters, based on the scope of the methods. Each cluster is composed of one or multiple methods, with similar properties, aims and objectives. The clusters, presented in Table 1, focus on capturing the variety of V\&V methods and their inputs and outputs. In order to increase the robustness of the classification, both researchers classified the V\&V methods into the clusters. The table found in the Appendix, contains in more detail the clusters, methods, sources and the subjects of the identified methods.

The clusters might extend to more than one lifecycle stage. By identifying at which stage the clusters were first introduced, the researchers managed to capture the process stage when the product's specifications have matured enough for a particular V\&V method to be applied. Table 1 contains the clusters of the V\&V methods per life stage. Due to size limitations of the paper, in-depth analysis of the methods contained in each cluster cannot be presented.

\subsection{PLM publications classification}

One of the investigated aspects of this study is to identify the focus of the implemented V\&V methods in terms of Verification, Validation or both. Figure 6, based on the detailed information presented in the Appendix, summarises the results of this analysis. Methods aimed mostly at verification constitute $14 \%$ of the whole sample, $19 \%$ focus on validation, and the rest $67 \%$ on both Verification and Validation. Most of the techniques/methods can be used for both Verification and Validation. Similar techniques have been used with a different focus and without applying strict boundaries as to whether they are referring to verification of validation. The key parameter that alters the focus of the method used is the scope of its implementation, whether it's verification of characteristics or validation of the design. As an example some papers used Testing for validation of the product (Jung et al., 2015), other papers for Verification of the characteristics (Lan, Arteau and Sirard, 2004; Santini-Bell et al., 2008) and 
(1)

(

some with a general focus on V\&V (Bucca et al., 2009; Pignataro, Lobaccaro and Zani, 2014). Thus, guidelines that strictly define which methods are most suitable for verification or validation have not been adequately developed yet.

Figure 6: Focus of the Methods

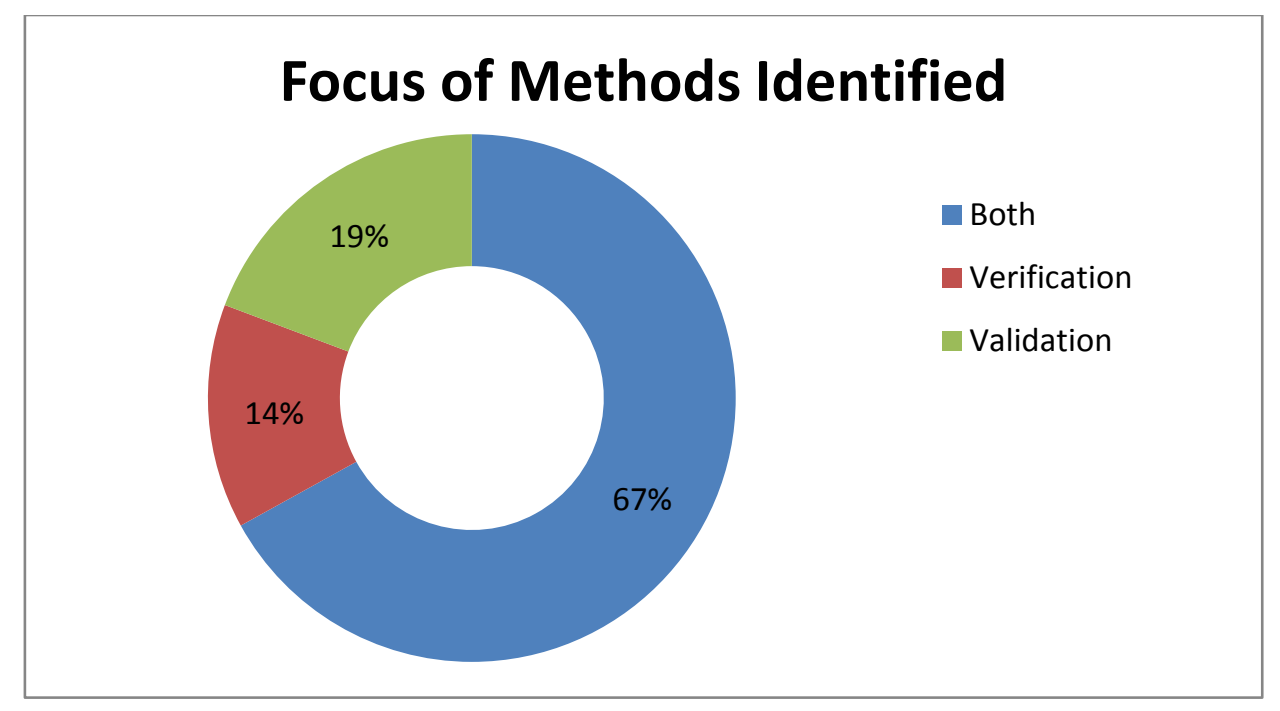

Table 1 contains the 20 clusters created for the 70 distinct identified methods. The aim of Table 1 is to illustrate to the reader the number of methods identified per cluster and the contribution of each cluster per product lifecycle stage, aggregating in total $100 \%$ for each stage. Moreover, through this analysis, it is evident that the cluster with the highest percentage is the dominant per stage. In the stages of Requirements Specification and Service/ Use, there are a limited number of clusters identified. On the other hand, in the Conceptual Design, Detail Design and Manufacturing \& Production there are multiple clusters used in the V\&V processes. This data underpins the large variety of $\mathrm{V} \& \mathrm{~V}$ methods focused on those stages in contrast with the limited methods on the Requirements and after manufacturing stages. This observation can raise once again the point that most of the $V \& V$ methods and techniques have a narrow focus on the three internal lifecycle stages, from Conceptual Design to Manufacturing. It becomes clear that $\mathrm{V} \& \mathrm{~V}$ is considered in academia an internal process with inadequate research focused on the external entities involved in the product's lifecycle.

Product development includes the stages of the requirements development, conceptual design and detail design. Based on Table 1, those three life stages are responsible for the $74 \%$ of the volume of all the $\mathrm{V} \& \mathrm{~V}$ activities, which proves that $\mathrm{V} \& \mathrm{~V}$ are processes focused in the first stages of definition of the project/product.

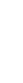




\begin{tabular}{|c|c|c|c|c|c|c|c|c|c|}
\hline \multirow[b]{2}{*}{$\begin{array}{l}\dot{\Xi} \\
\frac{\mathrm{D}}{\Xi} \\
\text { ž }\end{array}$} & \multirow[b]{2}{*}{ Clusters } & \multirow[b]{2}{*}{ 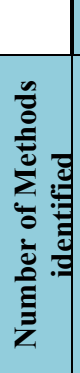 } & \multicolumn{7}{|c|}{ PLM Stages } \\
\hline & & & 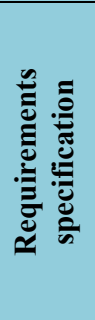 & 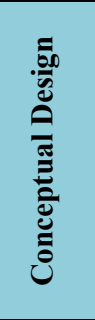 & 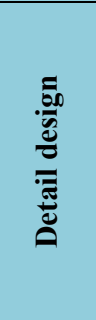 & 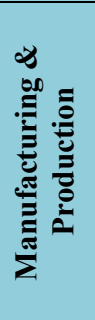 & 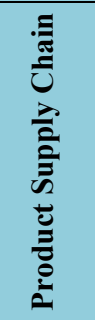 & 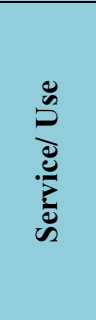 & 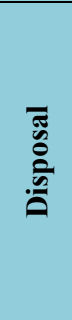 \\
\hline 1 & Knowledge Sharing & 5 & $16 \%$ & $8 \%$ & $5 \%$ & $6 \%$ & $7 \%$ & & \\
\hline 2 & Documentation & 1 & & & $1 \%$ & $3 \%$ & $7 \%$ & & \\
\hline 3 & Process Validation & 8 & $5 \%$ & $8 \%$ & $7 \%$ & $14 \%$ & $21 \%$ & & \\
\hline 4 & Validation Models & 3 & $11 \%$ & $4 \%$ & $3 \%$ & $3 \%$ & $7 \%$ & & \\
\hline 5 & Product Requirements/ Development & 9 & $32 \%$ & $17 \%$ & $5 \%$ & & & & \\
\hline 6 & CAD Software & 3 & & & $3 \%$ & $3 \%$ & $7 \%$ & & \\
\hline 7 & Information Management & 7 & $21 \%$ & $8 \%$ & $5 \%$ & $9 \%$ & $29 \%$ & $20 \%$ & \\
\hline 8 & Mathematical Based Method & 18 & $5 \%$ & $25 \%$ & $20 \%$ & & & & \\
\hline 9 & Physical Prototyping & 3 & & & $2 \%$ & $9 \%$ & & & \\
\hline 10 & Simulations & 10 & $5 \%$ & $12 \%$ & $12 \%$ & $9 \%$ & & & \\
\hline 11 & Testing & 9 & & $2 \%$ & $8 \%$ & $9 \%$ & & $20 \%$ & \\
\hline 12 & Numerical Analysis & 11 & & $4 \%$ & $9 \%$ & $14 \%$ & & $20 \%$ & \\
\hline 13 & Risk \& Assembly Analysis & 4 & & $2 \%$ & $5 \%$ & $3 \%$ & & & \\
\hline 14 & Systematic Optimisation Techniques & 3 & $5 \%$ & $4 \%$ & $2 \%$ & $3 \%$ & & & \\
\hline 15 & Digital Prototyping & 4 & & $4 \%$ & $5 \%$ & $3 \%$ & & & \\
\hline 16 & Virtual Reality Simulations & 3 & & $4 \%$ & $3 \%$ & & & & \\
\hline 17 & Regulations & 1 & & & $1 \%$ & $3 \%$ & & & \\
\hline 18 & Standards & 2 & & & $2 \%$ & $6 \%$ & $7 \%$ & & \\
\hline 19 & Metrology/Inspection & 2 & & & $1 \%$ & $6 \%$ & & & \\
\hline \multirow[t]{4}{*}{20} & Tracking Methods/Identification Methods & 3 & & & & & $14 \%$ & $40 \%$ & \\
\hline & Total (Methods with duplicates) & 109 & $100 \%$ & $100 \%$ & $100 \%$ & $100 \%$ & $100 \%$ & $100 \%$ & $0 \%$ \\
\hline & Total Clusters per Stage & & $8 / 20$ & $13 / 20$ & $19 / 20$ & $16 / 20$ & $8 / 20$ & $4 / 20$ & $0 / 20$ \\
\hline & Total (Distinct Methods) & 70 & & & & & & & \\
\hline
\end{tabular}

396 Figure 7, based on the appendix and Table 1, illustrates the clusters of the V\&V methods 397 classified against the multiple stages of the product's lifecycle. For the creation of this diagram, 398 it was assumed that if at least one of the cluster's methods has been applied in the selected 399 lifecycle stage, then the cluster is applicable at this stage. This classification created a 400 qualitative visual imprint of the applicability of the V\&V processes across the multiple stages 401 and the limits of each cluster. Thus, it provides the foundation for effective V\&V across the 402 product's lifecycle by illustrating the used clusters for V\&V per stage. As a result, it can be 403 used as a guideline for designers to identify the appropriate clusters of methods to use and aid 404 them in obtaining a holistic approach to the V\&V processes. 


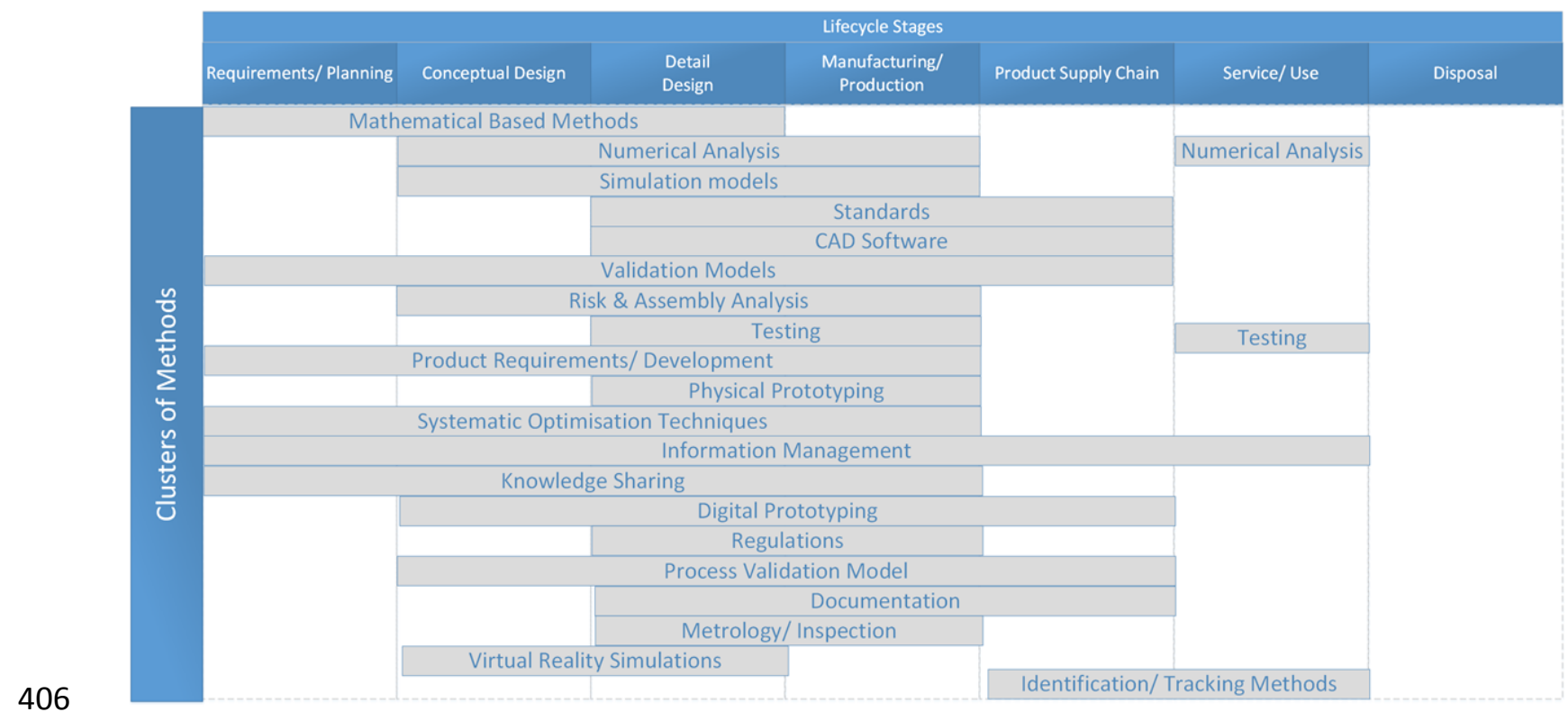

407

408 Figure 8, created by taking into consideration the number of methods constituting each cluster 409 per stage, illustrates the steep rise and fall of the V\&V processes used. The peak is spotted in 410 Detail Design, where the Validation Master Plan (VMP) is usually finalised. VMP is a 411 document that is common for heavily regulated sectors such as the pharmaceutical, medical 412 and biomechanical. It contains all the processes and equipment that will be validated during 413 the production, the main guidelines and who will be responsible for each process. Figure 8 also 414 highlights the scarcity of methods in the stages after manufacturing. 


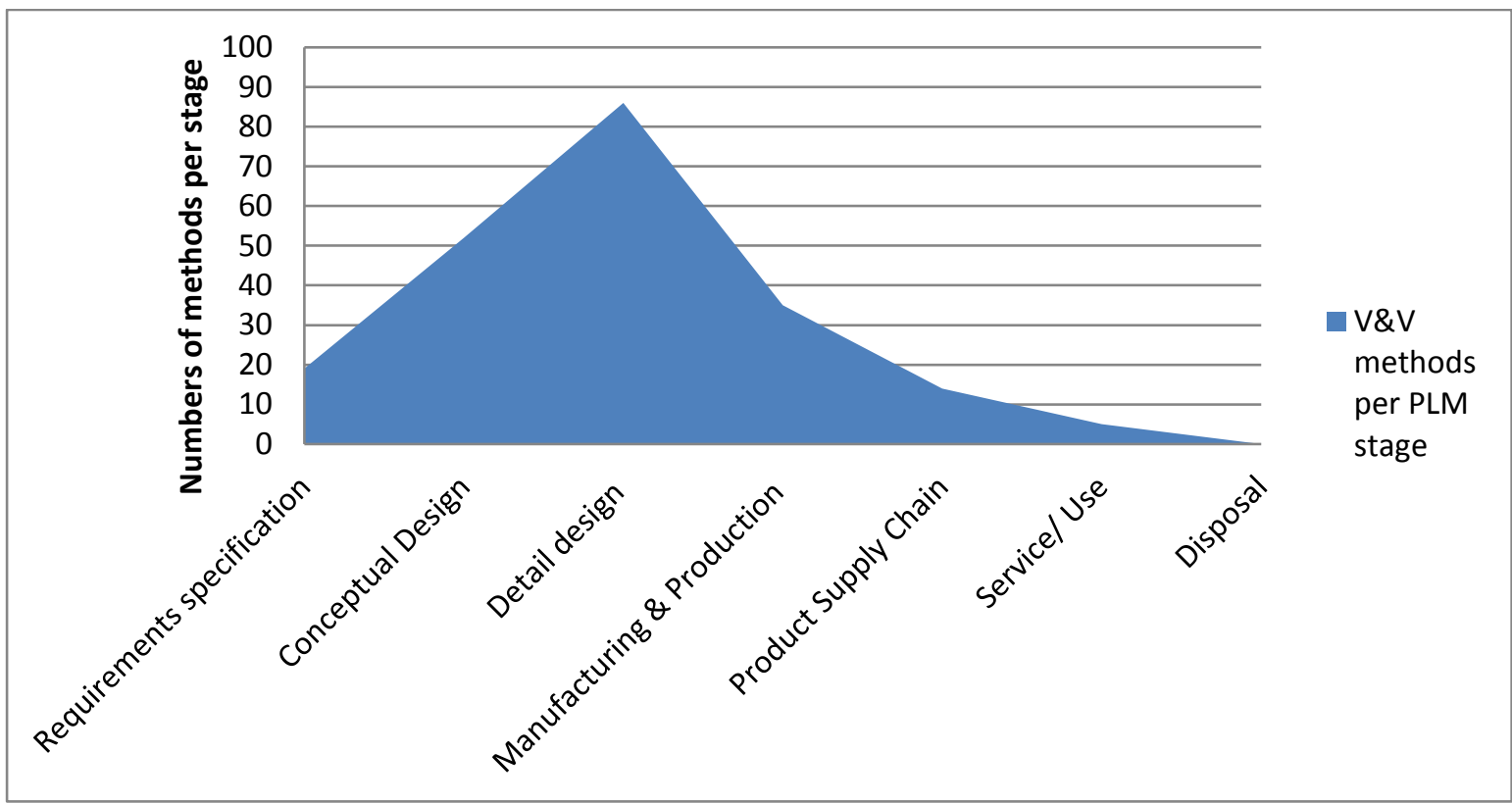

418 Finally, in Figure 9, the researchers synthesised the number of V\&V methods from Figure 8

419 with the distributed clusters across the PLM stages from Figure 7. Figure 9 is the main novelty of this systematic literature review and illustrates the results emerging from this research. It can provide the reader with various types of information such as the academic interest and efforts in the fields of V\&V for the period from 1990 to 2017, the lifecycle stage range of the clusters identified, the frequency of application of $\mathrm{V} \& \mathrm{~V}$ methods per lifecycle stage. This mapping of the $\mathrm{V} \& \mathrm{~V}$ processes across the product's lifecycle stages constitutes a novel 


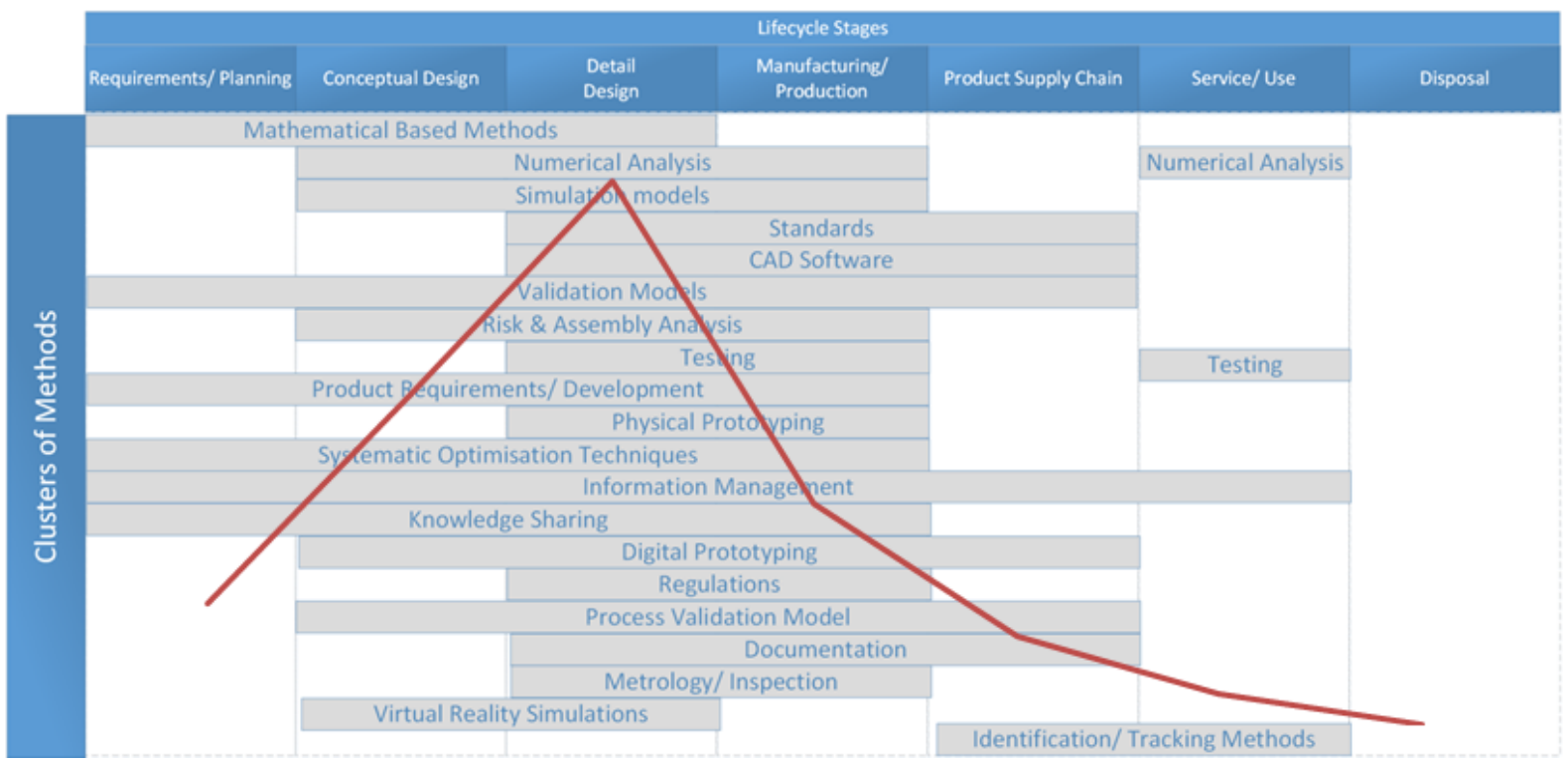

\section{Discussion}

This study answers the following research question: 'How Verification and Validation can be implemented across the product's lifecycle?'. The answer to this RQ provided multiple topics for discussions and inspired the researchers to identify and structure the pillars for adequate $\mathrm{V} \& \mathrm{~V}$ practices in a lifecycle perspective, resulting in a novel PLM based approach.

\subsection{Research question results analysis}

The analysis firstly focused on the identification of methods and techniques applied for $V \& V$, and secondly on the distribution of the methods across the lifecycle phases. The analysis of the 52 final articles has driven the answer to the RQ, leading to the guidelines presented herein.

One of the results of this study is that even if FDA is promoting V\&V as lifecycle processes, commonly applied practices fail to do so, at least as it can be seen in the relevant literature. $\mathrm{V} \& \mathrm{~V}$ is largely focused on the Conceptual and Detail Design phase with a steep decrease in frequency of use at the following lifecycle stages. During the stage of Manufacturing, $V \& V$ is mostly applied through Metrology/Inspection, and in the post-production phases, $\mathrm{V} \& \mathrm{~V}$ is alarmingly absent. Finally, in the stage of disposal, V\&V is completely missing with no method identified through the SLR that refers to that stage.

446 The researchers have created 20 distinct clusters with 70 distinct methods identified in the literature. This analysis answered the first part of the RQ, namely 'How Verification and Validation can be implemented', by identifying the relevant methods. The classification of 70 methods into 20 theme-related clusters has created a detailed mapping of the $\mathrm{V} \& \mathrm{~V}$ processes and the existing analysis opportunities for the product's characteristics. Analysis of those clusters provides fruitful insight, such as the lack of interest in academia for documentation, even if FDA guidelines require so. This has been defined as one of the factors that adversely affect V\&V processes (Aleem et al., 2003). The distribution of those clusters across the stages 
of the product's lifecycle, according to the information found through the literature review, provided the answer to the second part of the RQ 'across the product's lifecycle?'.

Moreover, this study was able to identify gaps in the fields of $\mathrm{V} \& \mathrm{~V}$, where additional research is needed. Validation is a much vaguer field than verification. Although organisations such as the FDA require validation as one of the prerequisites for approval of the product through regulation, there are no clear guidelines and processes to follow. Researchers have identified the need for further research on the standardisation of the validation concept (Duren, 2006). In the same direction (Kayis et al., 2007) highlighted the need for knowledge sharing and standardisation of the $\mathrm{V} \& \mathrm{~V}$ approach of refreshed products while others focused on the development of frameworks that provide clear and measurable V\&V goals (Aleem et al., 2003). Other researchers pointed out the need for governments to regulate regarding the $\mathrm{V} \& \mathrm{~V}$ for connected devices, such as smart devices, in an attempt to standardise and protect the data sharing (Wright, 2017).

Another important conclusion is that most of the researchers have identified the need for conformance comparison of a product against standards (Abramovici, O. Sieg, 2002a; Stark, 2005; PTC, 2008). On the other hand, V\&V of a product itself should not strictly be confined to one stage since successful $\mathrm{V} \& \mathrm{~V}$ requires actual data from all the product lifecycle stages. This one-stage $\mathrm{V} \& \mathrm{~V}$ practice is in contradiction with the identified need of $\mathrm{V} \& \mathrm{~V}$ becoming a lifecycle process (Aleem et al., 2003) and the FDA guidelines.

Other papers focused more on the need for formal methods, based on digital tools that can share Product Design Specifications (PDS) unambiguously and allow successful V\&V (Weissman et al., 2011; Li and Liu, 2016). Their research could be the answer to gaps such as regulations and automatic validation of the product's design, as this was defined by (Seo et al., 2015).

The primary outcomes of this qualitative and quantitative analysis are:

a) V\&V is not currently addressed as a lifecycle process by academia, although since 2011 guidelines from FDA promoted so.

b) There are limited clusters of methods that are focused on V\&V during the requirements specification stage. Verification occurs based on the Key Control Characteristics (KCCs) that the designers have developed, and Validation is questioning the correctness of the design. Poor selection of KCCs may lead to Verification failure while incorrectness in listening to the consumer's voice may lead to design's Validation failure.

c) The main focus of the V\&V processes seems to be in the Detail Design phase. All the clusters, with the only exemption of Tracking/Identification methods, are applicable at this stage. This results in creating a peak in the used processes of $V \& V$, reflected by the creation of VMP.

d) The steep increase that leads to the VMP peak is then followed by an almost equally steep decrease in practices of $\mathrm{V} \& \mathrm{~V}$ methods during the manufacturing and the postproduction stages. 
e) The interest in V\&V is limited at the stages of Product Supply Chain and Service/Use. Although the service/ use stage of the product lifecycle has been studied in the literature from various perspectives such as the customer's (Jun-Yeon et al., 2018), there are limited studies conducted from the V\&V perspective. This study points out this issue and raises the question to academia and industry, why V\&V is not currently applied to those phases, and what the impact of this absence is. Future research can search for the answer and aid in identifying the reasons why $\mathrm{V} \& \mathrm{~V}$ is not currently implemented as a lifecycle process.

f) Although the disposal of a product from an environmental perspective is of high interest, this is not the case for the $\mathrm{V} \& \mathrm{~V}$ practices perspective. According to the findings of this study, V\&V has not been focusing on that stage of the product's lifecycle. Validation of the design seems not to have created the crucial loop of information flow from the end of the lifecycle back to the designers, in order to provide update to the predictions made from the designers. Moreover, V\&V hasn't been linked with ideas such as reverse logistics, sustainability and circular economy. Another promising future research area for the field of $V \& V$ could be the integration of $V \& V$ with Quality Assurance and estimation models, focused on promoting Circular Economy practices such as reusing, refurbishing, recycling and disposal.

g) Finally, other studies concluded that Process Planning, a familiar and often prerequisite activity for $\mathrm{V} \& \mathrm{~V}$, is still at an immature level and more efforts should be committed to this cause (Maropoulos and Ceglarek, 2010).

\subsection{Verification and Validation Pillars for PLM approach}

Past studies identified the need for extending V\&V across two main directions. The first one refers to the adoption of a PLM approach, able to apply V\&V across the multiple product lifecycle stages (Maropoulos and Ceglarek, 2010; Sibois et al., 2014). The other direction is focused more on the entities integrated within the V\&V activities. Those studies underpinned the need for taking into consideration the suppliers (Kang, Rong and Yang, 2003; Al-Ashaab et al., 2012; Wakabayashi et al., 2017), external companies, and the end-user (Bahill and Henderson, 2005; Wright, 2017).

Up to now, various studies, applying an internal focus, defined that $\mathrm{V} \& \mathrm{~V}$ is based on three main pillars, a) inspection of geometrical specifications, b) the simulation of processes and, c) the detailed examinations of layouts (Wöhlke and Schiller, 2005). Those pillars can adequately describe $\mathrm{V} \& \mathrm{~V}$ activities only from an internal organisational perspective.

This study concluded that it is possible to integrate the lifecycle stages perspective with the external and the internal focus of the V\&V processes on the same approach. Thus, by analysing the created clusters, this study concludes that additional pillars should be constructed for implementation of a lifecycle approach to $V \& V$ and expansion of those activities beyond the internal organisational boundaries. This novel approach takes into consideration external stakeholders and entities such as the suppliers and the environment of the focal company, adopting a more holistic approach. This study suggests that additional pillars should be constructed based on the following groups: 
1) Validation of the product's requirements: This pillar should contain all the methods that are aiming to validate the correctness of the decisions that translate the customer needs into product characteristics and later specifications. Methods such QFD, TRIZ, AHP and other similar methods are able to provide a robust approach on which Key Characteristics (KCs) will be defined for the product and link the selection of those KCs with the users' expectations (Chin, Zheng and Wei, 2003; Filippi and Barattin, 2016). Other methods in later stages will be able to provide guidelines on how and which of those KCs will be transformed into Key Control Characteristics (KCCs) during the manufacturing stage.

2) Data Exchange: According to multiple studies a V\&V plan must unambiguously describe and define the data flow and take into consideration this exchange (Weissman, Petrov and Gupta, 2011; Shehab et al., 2013; Sanya and Shehab, 2015). Such a plan can indicate overlapping activities, prevent non-needed processes and keep production under the welldefined quality acceptance limits. This information exchange should describe the type of data that will accompany the digital twin of the product, the entities that will share the data, which data will be part of the feedback loop to previous lifecycle stages and also regulations that will protect the data.

3) Knowledge sharing: The importance of knowledge sharing lies in the fact that quality-related knowledge should be able to travel through the different members of the complex product supply chain and the lifecycle stages (Al-Ashaab et al., 2012). Previous studies have highlighted the advantages of supplier-customer integration in the design process (Fish, 2011). Other researches focused on investigating how testing results, a crucial piece of $\mathrm{V} \& \mathrm{~V}$ information, can efficiently interface with other value streams and travel among different stakeholders (Toche et al., 2017). Those cases of knowledge sharing among multiple stakeholders are crucial for providing insight and feedback on the product's lifecycle in a bidirectional way. This loop will provide the designers awareness for the late stages of the product after its manufacturing. The importance of knowledge sharing, and data sharing loops is increased when the product enters a circular economy scheme with the purposes of reusing, remanufacturing, recycling or disposal.

4) Regulations \& Documentation: Studies have shown that often designers are not aware of the regulations that define the market which their product is manufactured for (Kim et al., 2015) and that the industries and not the governments are the ones who push forward for additional regulations (Wright, 2017). Regulations are crucial for the effective V\&V of the product across its lifecycle. Moreover, documentation of the V\&V process should be aligned with each of the product's stages and provide valid information both for the physical and the digital twin of the product and support establishing the conformance against the standards.

5) PLM approach: Finally, by constructing the previous pillars, the organisation will be able to approach $V \& V$ as lifecycle processes. For $V \& V$ to be successfully transformed to lifecycle processes, all the pillars presented herein should be fully developed and able to provide support to each other. The need for a PLM approach to V\&V has been acknowledged multiple times in the literature (Maropoulos and Ceglarek, 2010). 
The proposed pillars create a novel approach on approaching V\&V from the PLM perspective since they capture both the internal and external focus and are based on the clusters developed for the multiple lifecycle stages of the product. Figure 10 illustrates both the established pillars (Wöhlke and Schiller, 2005) and the additional proposed pillars steming from this analysis. For $\mathrm{V} \& \mathrm{~V}$ to be addressed as lifecycle processes, those pillars should be equally developed, integrating multiple departments and stakeholders such as the focal company, suppliers, external companies, consumers and the regulation and institutional framework in which the company operates.

Figure 10: Suggested pillars for successful V\&V

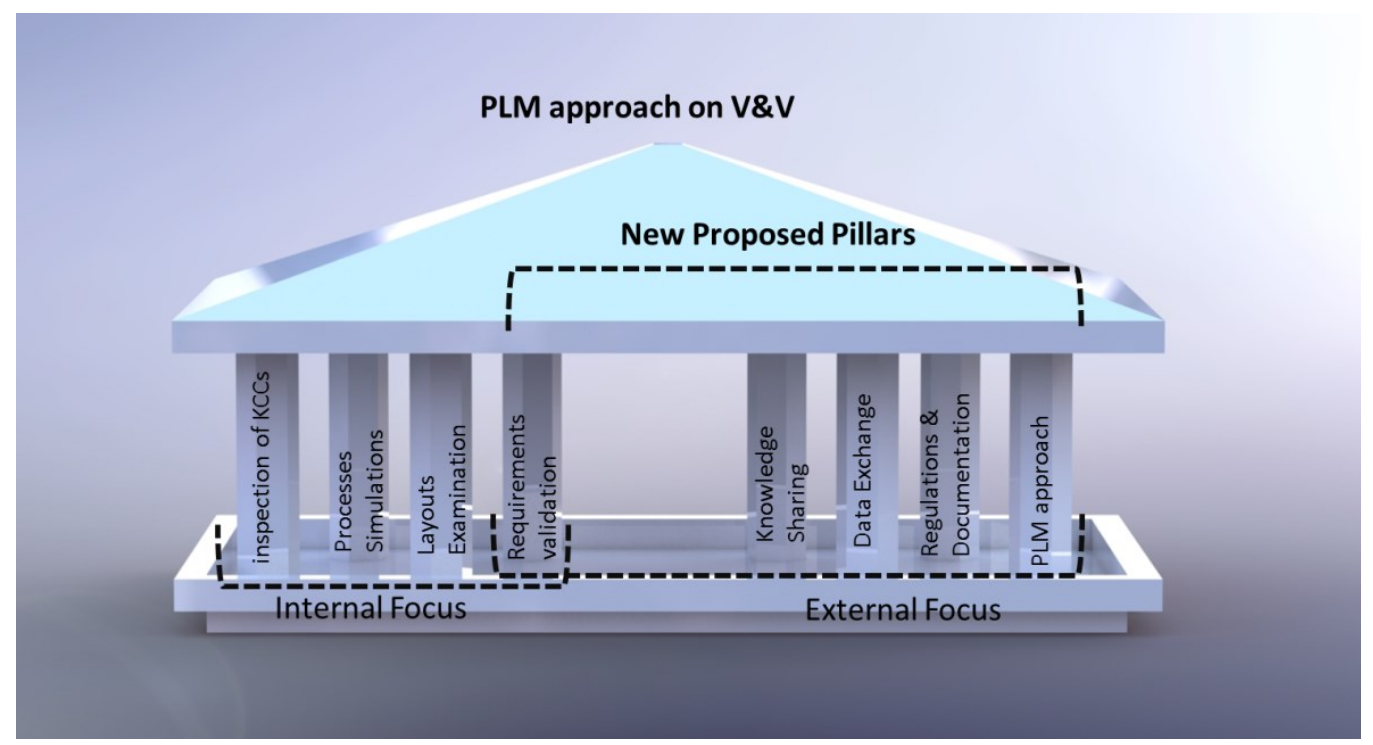

\section{Conclusions}

This study identified the methods and techniques applied for $\mathrm{V} \& \mathrm{~V}$, classifying them in 20 distinct clusters and distributing those clusters among the well-defined product lifecycle stages. The 52 papers analysed provided the methods applied for V\&V and were the raw data the researchers used to map the $\mathrm{V} \& \mathrm{~V}$ processes. The analysis and illustration of the 109 identified methods led to multiple findings and a depiction of the V\&V current state across the product's lifecycle.

This study identified gaps and trends in different stages of the related processes. It built the foundation for more focused further research. It also demonstrated the uneven distribution of $\mathrm{V} \& \mathrm{~V}$ practices usage in the product lifecycle and the limited frequency of use during the last lifecycle stages.

Moreover, it demonstrated that although $\mathrm{V} \& \mathrm{~V}$ is promoted as a lifecycle process from the FDA, in reality, it is focused almost exclusively on the stages of Conceptual and Detail Design. For the following stages of the lifecycle, V\&V is mostly applied through Metrology/ Inspection and, at the disposal stage, $\mathrm{V} \& \mathrm{~V}$ is completely absent.

Finally, based on the analysis of the selected papers, this research identified the crucial pillars for successful implementation of a lifecycle approach on V\&V. It questioned past practices 
which focused on only three internally-facing pillars (Wöhlke and Schiller, 2005) and developed a novel approach on V\&V from the PLM perspective which aims at extending V\&V practice beyond the internal organisational boundaries. This "eight pillars" plan can create strong foundations for the development of a fruitful and robust V\&V framework across the product lifecycle and provides ground for future studies. Such an approach is more beneficial for products produced in numbers with well-defined supply chain standards and manufacturing processes which extend beyond the internal organisational boundaries rather than design-toorder artefacts, since each of those artefacts may have different lifecycle requirements. Thus, this study contributes to knowledge by creating clusters that describe the V\&V practices, distributing those clusters across the product's lifecycle, identifying gaps on the current implementation of $\mathrm{V} \& \mathrm{~V}$, setting the foundation for future work on the related fields and most importantly, proposing a new approach addressing $\mathrm{V} \& \mathrm{~V}$ as both internal and external processes across the product's lifecycle.

\subsection{Research Limitations}

Adopting a systematic approach to a literature review does not make the research immune against limitations. The selection of the databases raises the first pragmatic limitation. Each database may offer different search functionality or sub-category classifications, requiring a subjective judgement from the researchers. Although effort has been put through joint discussion and decisions from the researchers to increase objectivity, there could potentially be some bias introduced due to these decisions. Secondly, the process of the literature requires some decisions that may not be strictly applied to one of the criteria. In those cases, it is in the researchers' critical ability to apply or not the criteria, potentially adding some subjectivity to the results. For addressing this issue, the authors worked independently on the classification of the methods and debated any differences in opinions, to increase the robustness.

\subsection{Future Work}

This paper was able to map the $V \& V$ processes across the product's lifecycle, to identify gaps in the literature and pinpoint the pillars that need to be addressed for $V \& V$ to extend beyond the organisational boundaries, providing a novel approach on how V\&V can be implemented across the product lifecycle. The identification of those gaps in combination with the development of the 20 clusters and the clear illustration of the $\mathrm{V} \& \mathrm{~V}$ practices during the product's lifecycle can provide the fertile ground for shaping future research on $\mathrm{V} \& \mathrm{~V}$ to provide support to the practitioners for lifecycle application of the V\&V processes. Another future direction of this study can be the implementation of this approach and quantitative analysis through a case study. Moreover, this study promotes further research in the after manufacturing phases and especially in the stage of disposal, where $\mathrm{V} \& \mathrm{~V}$ is inadequately practised and suggests the need for integration of large scale $V \& V$ practices within the Circular Economy loops as an innovative and promising field. Finally, as other researchers have identified (Wright, 2017), regulations and standardisation of the V\&V practices, data sharing and collaboration for technologies based on multiple connected devices is an emerging direction of $\mathrm{V} \& \mathrm{~V}$. 
643 The research was supported by a University of Strathclyde Research Studentship

\section{$644 \quad$ References}

645 Abramovici, O. Sieg, M. (2002a) 'Status and Development Trends of Product Lifecycle Management', 646 in Proceedings of IPPD2002. Wroclaw, Poland.

647 Abramovici, O. Sieg, M. (2002b) 'Status and future trends of product lifecycle management (PLM )

648 technology', in IPPD conference. Wroclaw, Poland.

649 Ahi, P. and Searcy, C. (2013) 'A comparative literature analysis of definitions for green and 650 sustainable supply chain management', Journal of Cleaner Production. Elsevier Ltd, 52, pp. 329-341. 651 doi: 10.1016/j.jclepro.2013.02.018.

Al-Ashaab, A. et al. (2012) 'Knowledge-based environment to support product design validation',

653 Knowledge-Based Systems. Elsevier B.V., 26, pp. 48-60. doi: 10.1016/j.knosys.2011.06.019.

Aleem, H. et al. (2003) 'Pharmaceutical process validation: An overview', Proceedings of the Institution of Mechanical Engineers, Part E: Journal of Process Mechanical Engineering, 217(2), pp. 141-151. doi: 10.1243/095440803766612801.

Allen, N. A., Shaffer, C. A. and Watson, L. T. (2005) 'Building modeling tools that support verification, 658 validation, and testing for the domain expert', Proceedings - Winter Simulation Conference, 2005, pp. 419-426. doi: 10.1109/WSC.2005.1574277.

660 Alvarez, J. C. (2015) 'Lean design for Six Sigma: An integrated approach to achieving product reliability and low-cost manufacturing', International Journal of Quality and Reliability Management, 32(8). doi: 10.1108/IJQRM-08-2012-0125.

Ameri, F. and Summers, J. D. (2008) 'An ontology for representation of fixture design knowledge',

Anjos, J. M. S., Coracini, G. K. and Villani, E. (2013) 'A proposal and verification of a software Software, 55. doi: 10.1016/j.advengsoft.2012.09.004.

Babuska, I. and Tinsley, J. (2004) 'Verification and validation in computational engineering and science: basic concepts', Comput. Methods Appl. Mech. Engrg, 193, pp. 4057-66. Available at: www.sciencedirect.com\%0Awww.elsevier.com/locatelcma. exhibited in famous failures', Systems Engineering, 8(1), pp. 1-14. doi: 10.1002/sys.20017. doi: 10.2514/1.1010408. 
682 Bharadia, P. D. and Jignyasha, A. B. (2006) 'A Review Of Current Implementation Strategies For Validation Of Cleaning Processes In The Pharmaceutical Industry', Journal of validation technology, 12(3), pp. 218-231.

685

686

687

688

689

690

691

692

693

694

695

696

697

698

699

700

701

702

703

704

705

706

707

708

709

710

711

712

713

714

715

716

717

Bouikni, N., Desrochers, A. and Rivest, L. (2006) 'A product feature evolution validation model for engineering change management', Journal of Computing and Information Science in Engineering, 6(2). doi: 10.1115/1.2194909.

Bucca, G. et al. (2009) 'A Mechatronic Device for the Rehabilitation of Ankle Motor Function', Journal of Biomechanical Engineering, 131(12), p. 125001. doi: 10.1115/1.4000083.

Cambronero, M. E., Valero, V. and Díaz, G. (2010) 'Verification of real-time systems design', Software Testing Verification and Reliability, 20(1). doi: 10.1002/stvr.405.

Campbell, C. (2014) 'FDA 2011 Process Validation Guidance: Lifecycle Compliance Model', PDA Journal of Pharmaceutical Science and Technology, 68(2), pp. 185-191. doi: 10.5731/pdajpst.2014.00972.

Chin, K.-S., Zheng, L.-Y. and Wei, L. (2003) 'A hybrid rough-cut process planning for quality', International Journal of Advanced Manufacturing Technology, 22(9-10). doi: 10.1007/s00170-0031618-x.

CIMdata (2020) All About PLM. Available at: https://www.cimdata.com/en/resources/about-plm.

Cole, D. et al. (2010) 'Blast-Resistant Electrical Equipment Shelters', IEEE Transactions on Industry Applications, 46(4), pp. 1311-1320.

Défossez, H. J. P. and Serhan, H. (2013) 'Managing design excellence tools during the development of new orthopaedic implants', Journal of Biomechanical Engineering, 135(11). doi: 10.1115/1.4025323.

Duren, R. M. (2006) 'Validation (not just verification) of deep space missions', Aerospace Conference, 2006 IEEE, p. 13. doi: 10.1109/AERO.2006.1656182.

FDA (2002) General Principles of Software Validation; Final Guidance for Industry and FDA Staff, U.S. Department Of Health and Human Services Food and Drug Administration Center for Devices and Radiological Health Center for Biologics Evaluation and Research.

Ferrise, F., Bordegoni, M. and Graziosi, S. (2013) 'A method for designing users' experience with industrial products based on a multimodal environment and mixed prototypes', Computer-Aided Design and Applications, 10(3). doi: 10.3722/cadaps.2013.461-474.

Filippi, S. and Barattin, D. (2016) 'IDGL, an interaction design framework based on systematic innovation and quality function deployment', International Journal on Interactive Design and Manufacturing, 10(2). doi: 10.1007/s12008-014-0231-6.

Fish, L. A. (2011) 'Supply Chain Quality Management', Quality. doi: 10.1007/s11104-005-3104-8.

Fyrileiv, O., Hørte, T. and Bergan, P. G. (1997) 'Simplified approach for analyzing concrete creep of the Heidrun TLP - A verification study', International Journal of Offshore and Polar Engineering, 7(3), pp. 168-173.

Gasbarri, P. et al. (2012) 'Control-oriented modelization of a satellite with large flexible appendages and use of worst-case analysis to verify robustness to model uncertainties of attitude control', Acta Astronautica, 81. doi: 10.1016/j.actaastro.2012.07.016. 
Goldsmith, M. (2010) ‘Good Practice Guide No. 118 -A Beginner’s Guide to Measurement’, Book, (118), p. 34.

Gopalakrishnan, G. and Fujimoto, R. (1993) 'Design and verification of the Rollback Chip using HOP: a case study of formal methods applied to hardware design', ACM Transactions on Computer Systems, 11(2), pp. 109-145. doi: 10.1145/151244.151245.

Hammett, P. C., Wahl, S. M. and Baron, J. S. (1999) 'Using flexible criteria to improve manufacturing validation during product development', Concurrent Engineering Research and Applications, 7(4), pp. 309-318.

Hazra, A. et al. (2012) 'Cohesive coverage management: Simulation meets formal methods', Journal of Electronic Testing: Theory and Applications (JETTA), 28(4), pp. 449-468. doi: 10.1007/s10836-0125308-1.

Huang, G. Q., Wright, P. K. and Newman, S. T. (2011) 'Wireless manufacturing : a literature review , recent developments, and case studies', 3052. doi: 10.1080/09511920701724934.

Huang, W. and Kong, Z. (2010) 'Process capability sensitivity analysis for design evaluation of multistage assembly processes', IEEE Transactions on Automation Science and Engineering, 7(4). doi: 10.1109/TASE.2009.2034633.

ISO (2005) 'ISO 9000: Quality management systems - fundamentals ans vocabulary', 2005, pp. 1-30.

Jack Feng, C.-X. and Wang, X.-F. D. (2004) 'Data mining techniques applied to predictive modeling of the knurling process', IIE Transactions (Institute of Industrial Engineers), 36(3). doi: 10.1080/07408170490274214.

Jesson, J.K., Matheson, L. and Lacey, F. M. (2011) Doing Your Literature Review. London: Sage. Joint Committee For Guides In Metrology (2012) 'Vocabulaire international de métrologie', VIM3: International Vocabulary of Metrology, 3(third), p. 104. doi: 10.1016/0263-2241(85)90006-5.

Jun-Yeon, H., Chiehyeon, L. and Kwang-Jae, K. (2018) 'A customer-oriented model of product-service system lifecycle', International Journal of Product Lifecycle Management (IJPLM), 11(4), pp. 350-367.

Jung, Byung C. et al. (2015) 'A framework of model validation and virtual product qualification with limited experimental data based on statistical inference', Structural and Multidisciplinary Optimization, 51(3), pp. 573-583. doi: 10.1007/s00158-014-1155-2.

Jung, B.C. et al. (2015) 'A framework of model validation and virtual product qualification with limited experimental data based on statistical inference', Structural and Multidisciplinary Optimization, 51(3). doi: 10.1007/s00158-014-1155-2.

Kahn, K. et al. (2003) Systematic reviews to support evidence based medicine, Royal Society Medicine Press. London.

Kang, Y., Rong, Y. and Yang, J. a. (2003) 'Geometric and Kinetic Model Based Computer-Aided Fixture Design Verification', Journal of Computing and Information Science in Engineering, 3(3), p. 187. doi: 10.1115/1.1607352.

Kayis, B. et al. (2007) 'IRMAS - Development of a risk management tool for collaborative multi-site, multi-partner new product development projects', Journal of Manufacturing Technology Management, 18(4). doi: 10.1108/17410380710743770.

Keefe, D. F. et al. (2010) ‘A process for design, verification, validation, and manufacture of medical 
devices using immersive VR environments', Journal of Medical Devices, Transactions of the ASME, 4(4). doi: 10.1115/1.4002561.

Kim, l. et al. (2015) 'Verification of product design using regulation knowledgebase and Web services', Journal of Mechanical Science and Technology, 29(12), pp. 5113-5119. doi: 10.1007/s12206-015-1109-7.

Krishnamurthy, N. et al. (2000) 'Validating PowerPC microprocessor custom memories', IEEE Design and Test of Computers, 17(4), pp. 61-76. doi: 10.1109/54.895007.

Kundu, S., Lerner, S. and Gupta, R. (2009) 'High-Level Verification', IPSJ Transactions on System LSI Design Methodology, 2. doi: 10.2197/ipsjtsldm.2.131.

Lan, A., Arteau, J. and Sirard, C. (2004) 'Method for validating a multi-component safety system', Safety Science, 42(6). doi: 10.1016/j.ssci.2003.08.002.

Lari, A. (2017) 'An integrated information system for quality management', Journal of Health Organization and Management, 31(1), pp. 110-124. doi: 10.1108/JHOM-09-2016-0165.

Lewis, D. et al. (2005) 'Implementing laser based failure analysis methodologies using test vehicles', IEEE TRANSACTIONS ON SEMICONDUCTOR MANUFACTURING, 18(May), pp. 279-288.

Li, M. and Liu, S. (2016) 'Integrating Animation-Based Inspection into Formal Design Specification Construction for Reliable Software Systems', IEEE Transactions on Reliability, 65(1). doi: 10.1109/TR.2015.2456853.

Li, Z. and Chang, C. C. (2012) 'Tracking of Structural Dynamic Characteristics Using Recursive Stochastic Subspace Identification and Instrumental Variable Technique', 138(June), pp. 591-600. doi: 10.1061/(ASCE)EM.1943-7889.0000370.

Liu, W. et al. (2009) 'Product Lifecycle Management: A Survey', Volume 2: 29th Computers and Information in Engineering Conference, Parts $A$ and B, (September), pp. 1213-1225. doi: 10.1115/DETC2009-86983.

Majeske, K. D. and Hammett, P. C. (2003) 'Predicting assembly dimensions with functional build: A case study using DOE', Journal of Manufacturing Processes, 5(1). doi: 10.1016/S15266125(03)70041-3.

Maropoulos, P. G. and Baker, R. P. (2000) 'Integration of tool selection with design Part 1. Feature creation and selection of operations and tools', Journal of Materials Processing Technology, 107(13). doi: 10.1016/S0924-0136(00)00686-5.

Maropoulos, P. G. and Ceglarek, D. (2010) 'Design verification and validation in product lifecycle', CIRP Annals - Manufacturing Technology, 59(2), pp. 740-759. doi: 10.1016/j.cirp.2010.05.005.

Pignataro, M. A., Lobaccaro, G. and Zani, G. (2014) 'Digital and physical models for the validation of sustainable design strategies', Automation in Construction, 39. doi: 10.1016/j.autcon.2013.11.006.

PTC (2008) Managing the Total Product Life Cycle.

Ramani, K. et al. (2010) 'Integrated Sustainable Life Cycle Design: A Review', Journal of Mechanical Design, 132(9), p. 091004. doi: 10.1115/1.4002308.

Santini-Bell, E. et al. (2008) 'Nondestructive testing for design verification of Boston's Central Artery underpinning frames and connections', Bridge Structures, 4(2), pp. 87-98. doi: $10.1080 / 15732480802246337$. 
801

802

803

804

805

806

807

808

809

810

811

812

813

814

815

816

817

818

819

820

821

822

823

824

825

826

827

828

829

830

831

832

833

834

835

836

837

838

839

840

841

Sanya, I. O. and Shehab, E. M. (2015) 'A framework for developing engineering design ontologies within the aerospace industry', International Journal of Production Research, 53(8). doi: 10.1080/00207543.2014.965352.

Sauza Bedolla, J. et al. (2013) Fostering PLM implementation in SMEs: Modelling and managing verification processes, IFAC Proceedings Volumes (IFAC-PapersOnline). IFAC. doi: 10.3182/201306193-RU-3018.00489.

Schwer, L. E. (2007) 'An overview of the PTC 60/V\&V 10: Guide for verification and validation in computational solid mechanics: Transmitted by L. E. Schwer, Chair PTC 60V\&V 10', Engineering with Computers, 23(4), pp. 245-252. doi: 10.1007/s00366-007-0072-z.

Seo, D.-S., Kim, B.-J. and Lee, M. (2015) 'Vision-Inspection System for Residue Monitoring of ReadyMixed Concrete Trucks', Advances in Materials Science and Engineering, 2015. doi: 10.1155/2015/175951.

Shehab, E. et al. (2013) 'Enhancement of product information collaboration and access in the aerospace industry', International Journal of Production Research, 51(11). doi: 10.1080/00207543.2012.754965.

Shen, J. and Abraham, J. A. (2000) 'An RTL Abstraction Technique for Processor Microarchitecture Validation and Test Generation', Journal of Electronic Testing, 81, pp. 67-81. doi: 10.1023/A:1008388623771.

Sherman, M. (2015) The Medical Device Validation Handbook. Edited by MD: Regulatory Affairs Professionals Society. Rockville.

Sibois, R. et al. (2014) 'Simulation-based design process for the verification of ITER remote handling systems', Fusion Engineering and Design, 89(9-10). doi: 10.1016/j.fusengdes.2014.02.049.

Stark, J. (2005) Product Lifecycle Management - 21th Century Paradigm for Product Realisation, Springer. London.

Stark, R., Kind, S. and Neumeyer, S. (2017) 'Innovations in digital modelling for next generation manufacturing system design', CIRP Annals - Manufacturing Technology, 66(1). doi: 10.1016/j.cirp.2017.04.045.

Suresh, C. K. H., Ozev, S. and Sinanoglu, O. (2015) 'Adaptive generation of unique IDs for digital chips through analog excitation', ACM Transactions on Design Automation of Electronic Systems, 20(3). doi: $10.1145 / 2732408$.

Toche, B. et al. (2017) 'A framework to support collaboration during prototyping and testing', International Journal of Product Lifecycle Management, 10(4), p. 348. doi: 10.1504/IJPLM.2017.090329.

Tranfield, D., Denyer, D. and Smart, P. (2003) 'Towards a methodology for developing evidenceinformed management knowledge by means of systematic review', British Journal of Management, 14(3), pp. 207-222.

Urbanic, R. J. and Elmaraghy, W. H. (2009) 'Using a modified failure modes and effects analysis within the structured design recovery framework', Journal of Mechanical Design, Transactions of the ASME, 131(11). doi: 10.1115/1.3201968.

US Department of the Navy (DON) (2004) Modeling and Simulation Verification, Validation, and Accreditation Implementation Handbook, Department of the Navy -USA. 
842 Verein Deutscher Ingenieure (VDI) (2002) 'VDI 2219 - Information technology in product

843 development Introduction and economics of EDM/PDM Systems (Issue German/English)', 2219, p.

8442219.

845 Vyatkin, V. et al. (2009) 'Closed-loop modeling in future automation system engineering and

846 validation', IEEE Transactions on Systems, Man and Cybernetics Part C: Applications and Reviews,

847 39(1). doi: 10.1109/TSMCC.2008.2005785.

848 Wakabayashi, Y. et al. (2017) 'Developing a Practical Method for Validation of Computerized Systems

849 Integrated With Smart and/or Wearable Devices for Regulatory Compliance of Clinical Trials',

850 Therapeutic Innovation and Regulatory Science, 51(1), pp. 118-124. doi:

$85110.1177 / 2168479016666585$.

852 Weissman, A., Petrov, M. and Gupta, S. K. (2011) 'A computational framework for authoring and 853 searching product design specifications', Advanced Engineering Informatics. Elsevier Ltd, 25(3), pp. 854 516-534. doi: 10.1016/j.aei.2011.02.001.

855 Witherell, P. et al. (2010) 'Improved knowledge management through first-order logic in engineering 856 design ontologies', Artificial Intelligence for Engineering Design, Analysis and Manufacturing:

857 AIEDAM, 24(2). doi: 10.1017/S0890060409990096.

858 Wöhlke, G. and Schiller, E. (2005) 'Digital Planning Validation in automotive industry', Computers in 859 Industry, 56(4). doi: 10.1016/j.compind.2005.01.010.

860 Wright, C. (2017) 'Connencted Devive System Validation \& Quality- Best practices', Institute of 861 validation Technology.

862 Yan, X. et al. (2008) 'Aerodynamic Design, Model Test, and CFD Analysis for a Multistage Axial 863 Helium Compressor', Journal of Turbomachinery, 130(3), pp. 1-12. doi: 10.1115/1.2777190.

864 Yang, C.-H., Vyatkin, V. and Pang, C. (2014) 'Model-Driven Development of Control Software for 865 Distributed Automation: A Survey and an Approach', IEEE Transactions on Systems, Man, and 866 Cybernetics: Systems, 44(3). doi: 10.1109/TSMCC.2013.2266914.

867 Zbrozek, A. et al. (2013) 'Validation of electronic systems to collect patient-reported outcome (PRO) 868 data - Recommendations for clinical trial teams: Report of the ISPOR ePRO systems validation good 869 research practices task force', Value in Health, 16(4), pp. 480-489. doi: 10.1016/j.jval.2013.04.002.

870 Zhou, J. et al. (2015) 'A quantitative characterization of cross coverage', IEEE Transactions on

871 Computers, 64(8), pp. 2408-2414. doi: 10.1109/TC.2014.2360540. 


\section{$874 \quad$ Appendix}

875

876 Appendix Table: Full list of articles analysed in this study

877 


\begin{tabular}{|c|c|c|c|c|c|c|c|c|c|c|c|}
\hline & \multicolumn{7}{|c|}{ Lifecycle Stages } & & & & \\
\hline Reference & 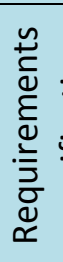 & 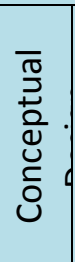 & 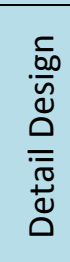 & 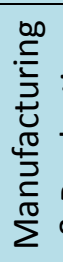 & 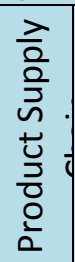 & 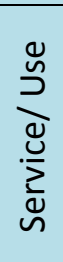 & $\begin{array}{l}\bar{\pi} \\
\tilde{0} \\
\frac{0}{n} \\
\frac{n}{0}\end{array}$ & Primary Subject of V\&V & $\begin{array}{l}\text { Verification/ } \\
\text { Validation or } \\
\text { both }\end{array}$ & $\begin{array}{l}\text { Methods } \\
\text { described }\end{array}$ & $\begin{array}{c}\text { Group that the Method } \\
\text { belongs }\end{array}$ \\
\hline $\begin{array}{c}\text { (Al-Ashaab et al., } \\
\text { 2012) }\end{array}$ & $x$ & $x$ & $x$ & & & & & $\begin{array}{l}\text { Refresh projects (projects } \\
\text { with minor changes in } \\
\text { comparison with previous } \\
\text { ones) }\end{array}$ & Validation & $\begin{array}{l}\text { Knowledge-based } \\
\text { approach }\end{array}$ & Knowledge Sharing \\
\hline \multirow{3}{*}{$\begin{array}{l}\text { (Aleem et al., } \\
\text { 2003) }\end{array}$} & & & $\mathrm{X}$ & $x$ & $\mathrm{X}$ & & & Validation Master Plan & Both & Documentation & Documentation \\
\hline & & & $\mathrm{X}$ & $\mathrm{x}$ & $X$ & & & $\begin{array}{l}\text { Pharmaceutical product's } \\
\text { specifications test of } \\
\text { conformance }\end{array}$ & Both & $\begin{array}{l}\text { Process validation } \\
\text { Method }\end{array}$ & Process Validation \\
\hline & & & $x$ & $\mathrm{x}$ & $x$ & & & $\begin{array}{l}\text { Modelling Validation } \\
\text { Activity }\end{array}$ & Validation & eValid & Validation Models \\
\hline \multirow{2}{*}{ (Alvarez, 2015) } & $x$ & $X$ & & & & & & $\begin{array}{l}\text { Advanced product quality } \\
\text { process }\end{array}$ & Validation & Lean Six Sigma & $\begin{array}{c}\text { Product Requirements/ } \\
\text { Development }\end{array}$ \\
\hline & $x$ & $x$ & & & & & & $\begin{array}{l}\text { Increase product reliability } \\
\text { and minimisation of } \\
\text { production costs }\end{array}$ & Both & $\begin{array}{l}\text { New Product } \\
\text { development } \\
\text { (NPD) }\end{array}$ & $\begin{array}{c}\text { Product Requirements/ } \\
\text { Development }\end{array}$ \\
\hline \multirow{2}{*}{$\begin{array}{c}\text { (Ameri and } \\
\text { Summers, 2008) }\end{array}$} & & & $\mathrm{X}$ & $\mathrm{x}$ & $\mathrm{X}$ & & & Fixture properties & Both & CAFD & CAD Software \\
\hline & & & $x$ & $\mathrm{x}$ & $x$ & & & FIXON ontology & Both & $\begin{array}{l}\text { Information } \\
\text { Management (DL } \\
\text { Language) }\end{array}$ & $\begin{array}{l}\text { Information } \\
\text { Management }\end{array}$ \\
\hline
\end{tabular}




\begin{tabular}{|c|c|c|c|c|c|c|c|c|c|}
\hline \multirow{2}{*}{$\begin{array}{l}\text { (Anjos, Coracini } \\
\text { and Villani, 2013) }\end{array}$} & & $x$ & $x$ & & & UPAAL Model checking & Verification & Formal Verification & $\begin{array}{c}\text { Mathematical Based } \\
\text { Method }\end{array}$ \\
\hline & & & $x$ & & & $\begin{array}{l}\text { Defining the set of test } \\
\text { cases to check the } \\
\text { software product }\end{array}$ & Both & $\begin{array}{l}\text { Conformance \& } \\
\text { Fault Injection } \\
\text { (CoFI) }\end{array}$ & $\begin{array}{c}\text { Mathematical Based } \\
\text { Method }\end{array}$ \\
\hline \multirow{3}{*}{$\begin{array}{l}\text { (Balachandran, } \\
\text { Ozay and Atkins, } \\
\text { 2016) }\end{array}$} & & & $x$ & & & Model Checking & Both & Formal Verification & $\begin{array}{c}\text { Mathematical Based } \\
\text { Method }\end{array}$ \\
\hline & & $\mathrm{x}$ & $x$ & & & $\begin{array}{l}\text { The correctness of the } \\
\text { design with respect to } \\
\text { system requirements }\end{array}$ & Both & $\begin{array}{l}\text { Deductive } \\
\text { techniques }\end{array}$ & $\begin{array}{c}\text { Mathematical Based } \\
\text { Method }\end{array}$ \\
\hline & $x$ & $\mathrm{x}$ & $x$ & & & System Engineering & Both & $V$ model & Validation Models \\
\hline $\begin{array}{l}\text { (Bharadia and } \\
\text { Jignyasha, 2006) }\end{array}$ & & & & $\mathrm{x}$ & $\mathrm{x}$ & $\begin{array}{l}\text { Cleaning validation } \\
\text { production program }\end{array}$ & Validation & $\begin{array}{l}\text { Process validation } \\
\text { of Cleaning }\end{array}$ & Process Validation \\
\hline $\begin{array}{l}\text { (Bouikni, } \\
\text { Desrochers and } \\
\text { Rivest, 2006) }\end{array}$ & $x$ & $x$ & & & & $\begin{array}{l}\text { Information flow for } \\
\text { support of Product } \\
\text { Definition Evolution (PDE) }\end{array}$ & Validation & $\begin{array}{l}\text { Product Feature } \\
\quad \text { Evolution } \\
\text { Validation (PFEV) }\end{array}$ & $\begin{array}{l}\text { Information } \\
\text { Management }\end{array}$ \\
\hline \multirow{3}{*}{$\begin{array}{l}\text { (Bucca et al., } \\
\text { 2009) }\end{array}$} & & & & $\mathrm{x}$ & & $\begin{array}{l}\text { Analysis of the MecDEAR } \\
\text { digital prototype of the } \\
\text { medical device }\end{array}$ & Both & $\begin{array}{l}\text { Physical } \\
\text { Prototyping }\end{array}$ & Physical Prototyping \\
\hline & & & $x$ & $\mathrm{x}$ & & $\begin{array}{l}\text { Working Conditions of the } \\
\text { medical device }\end{array}$ & Validation & simulations & Simulations \\
\hline & & & $x$ & $x$ & & $\begin{array}{l}\text { Validation of the bio } \\
\text { mechatronic mathematical } \\
\text { model }\end{array}$ & Both & Testing & Testing \\
\hline
\end{tabular}




\begin{tabular}{|c|c|c|c|c|c|c|c|c|}
\hline \multirow{3}{*}{$\begin{array}{l}\text { (Cambronero, } \\
\text { Valero and Díaz, } \\
\text { 2010) }\end{array}$} & & $x$ & $x$ & & UPAAL Model checking & Both & Formal Verification & $\begin{array}{c}\text { Mathematical Based } \\
\text { Method }\end{array}$ \\
\hline & & $x$ & $x$ & & $\begin{array}{c}\text { Behaviour analysis of } \\
\text { discrete dynamical systems } \\
\text { with timing restrictions }\end{array}$ & & Timed Automata & $\begin{array}{c}\text { Mathematical Based } \\
\text { Method }\end{array}$ \\
\hline & $x$ & $X$ & $x$ & & Requirements analysis & Verification & KAOS & $\begin{array}{l}\text { Product Requirements/ } \\
\text { Development }\end{array}$ \\
\hline \multirow{4}{*}{$\begin{array}{l}\text { (Chin, Zheng and } \\
\text { Wei, 2003) }\end{array}$} & & & & $x$ & $\begin{array}{c}\text { Assessment of the quality } \\
\text { process }\end{array}$ & Both & $\begin{array}{l}\text { Process Capability } \\
\text { Analysis CPP }\end{array}$ & Numerical Analysis \\
\hline & & $x$ & $x$ & $x$ & $\begin{array}{l}\text { RPPFQ for alternatives } \\
\text { quality processes }\end{array}$ & Both & Process Planning & Process Validation \\
\hline & & $X$ & & & $\begin{array}{c}\text { Translation of quality } \\
\text { characteristics into process } \\
\text { elements }\end{array}$ & Both & $\begin{array}{l}\text { Quality Function } \\
\text { Deployment (QFD) }\end{array}$ & $\begin{array}{l}\text { Product Requirements/ } \\
\text { Development }\end{array}$ \\
\hline & & & $X$ & $X$ & $\begin{array}{l}\text { Analysis of production } \\
\text { problems }\end{array}$ & Both & $\begin{array}{l}\text { Failure Mode } \\
\text { Effects Analysis } \\
\text { (FMEA) }\end{array}$ & $\begin{array}{l}\text { Risk \& Assembly } \\
\text { Analysis }\end{array}$ \\
\hline \multirow{2}{*}{ (Cole et al., 2010) } & & & $x$ & & $\begin{array}{c}\text { Structural verification of } \\
\text { the design }\end{array}$ & Both & $\begin{array}{l}\text { Finite Element } \\
\text { Analysis (FEA) }\end{array}$ & $\begin{array}{c}\text { Mathematical Based } \\
\text { Method }\end{array}$ \\
\hline & & & $x$ & & $\begin{array}{l}\text { Structural verification of } \\
\text { the design }\end{array}$ & Both & $\begin{array}{c}\text { Degree of Freedom } \\
\text { Analysis }\end{array}$ & Numerical Analysis \\
\hline $\begin{array}{l}\text { (Défossez and } \\
\text { Serhan, 2013) }\end{array}$ & & & $x$ & & $\begin{array}{l}\text { Tissue Testing for } \\
\text { validation model } \\
\text { development }\end{array}$ & Both & $\begin{array}{l}\text { Biomechanical } \\
\text { Testing }\end{array}$ & Testing \\
\hline
\end{tabular}




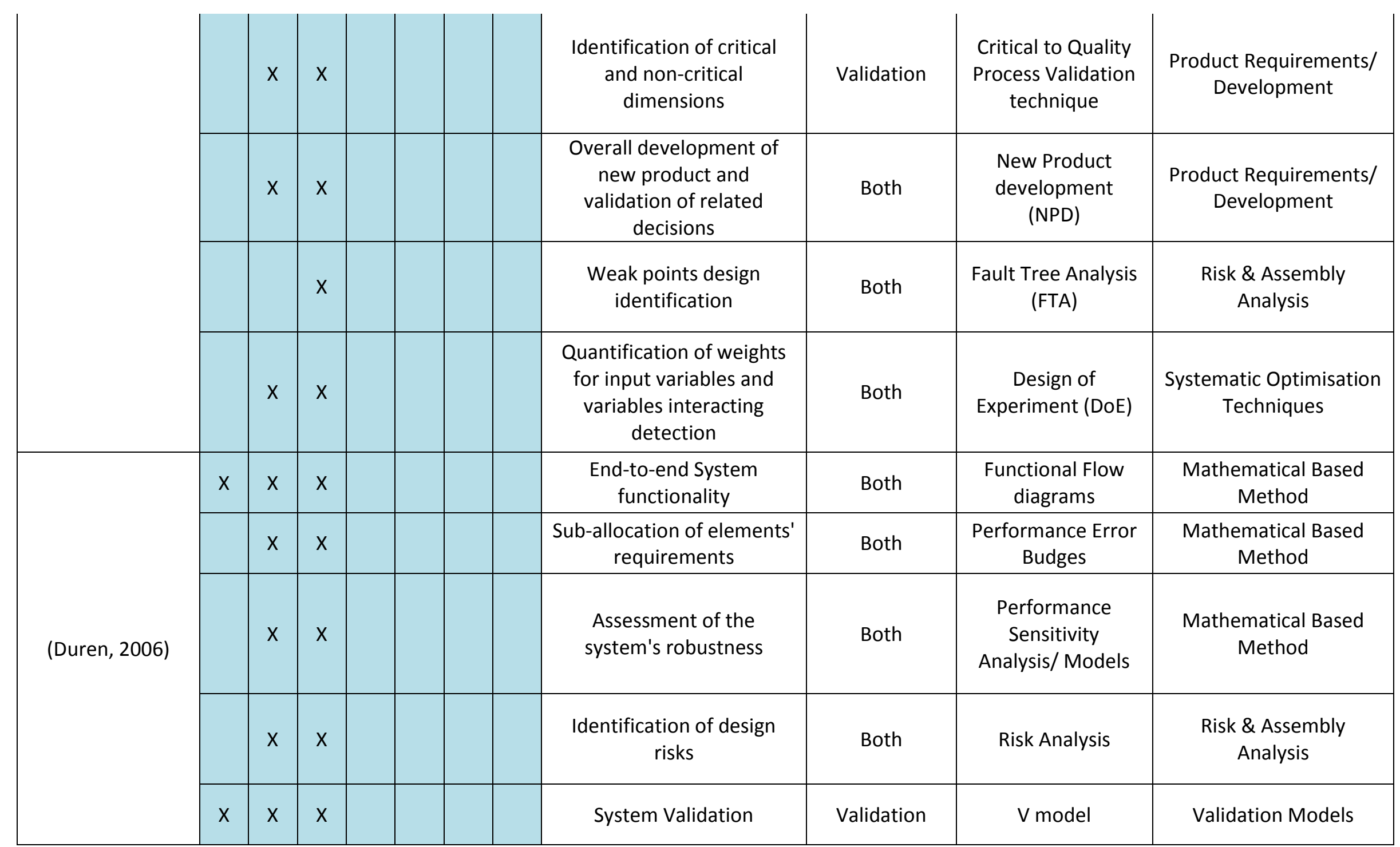




\begin{tabular}{|c|c|c|c|c|c|c|c|c|}
\hline \multirow{2}{*}{$\begin{array}{l}\text { (Ferrise, } \\
\text { Bordegoni and } \\
\text { Graziosi, 2013) }\end{array}$} & & & $x$ & & $\begin{array}{l}\text { Development of a mixed } \\
\text { prototype method }\end{array}$ & Both & Virtual prototyping & Digital Prototyping \\
\hline & & & $x$ & $x$ & $\begin{array}{l}\text { Development of a mixed } \\
\text { prototype method }\end{array}$ & Both & Physical Prototype & Physical Prototyping \\
\hline \multirow[t]{2}{*}{$\begin{array}{c}\text { (Filippi and } \\
\text { Barattin, 2016) }\end{array}$} & $x$ & $x$ & & & $\begin{array}{l}\text { Mapping the customer } \\
\text { needs and the product } \\
\text { requirements }\end{array}$ & Validation & $\begin{array}{l}\text { Quality Function } \\
\text { Deployment (QFD)- } \\
\text { House of Quality } \\
\text { (HOQ) }\end{array}$ & $\begin{array}{l}\text { Product Requirements/ } \\
\text { Development }\end{array}$ \\
\hline & $x$ & $x$ & & & $\begin{array}{l}\text { Development of an } \\
\text { innovative tool focused on } \\
\text { interaction design }\end{array}$ & Both & TRIZ & $\begin{array}{l}\text { Product Requirements/ } \\
\text { Development }\end{array}$ \\
\hline $\begin{array}{l}\text { (Fyrileiv, Hørte } \\
\text { and Bergan, } \\
\text { 1997) }\end{array}$ & & & $x$ & & $\begin{array}{c}\text { Study of the creep effect of } \\
\text { a composite steel-concrete } \\
\text { structure }\end{array}$ & Verification & $\begin{array}{l}\text { Finite Element } \\
\text { Analysis (FEA) }\end{array}$ & $\begin{array}{c}\text { Mathematical Based } \\
\text { Method }\end{array}$ \\
\hline \multirow{2}{*}{$\begin{array}{l}\text { (Gasbarri et al., } \\
\text { 2012) }\end{array}$} & & & $x$ & & $\begin{array}{l}\text { Testing the design's } \\
\text { robustness }\end{array}$ & Verification & $\begin{array}{l}\text { Monte-Carlo } \\
\text { Simulation }\end{array}$ & Numerical Analysis \\
\hline & & & $x$ & & $\begin{array}{l}\text { Testing the design's } \\
\text { robustness }\end{array}$ & Both & $\begin{array}{l}\text { Worst-Case } \\
\text { Analysis }\end{array}$ & $\begin{array}{l}\text { Risk \& Assembly } \\
\text { Analysis }\end{array}$ \\
\hline $\begin{array}{c}\text { (Gopalakrishnan } \\
\text { and Fujimoto, } \\
\text { 1993) }\end{array}$ & & $x$ & $x$ & & $\begin{array}{l}\text { Analysis of the design of a } \\
\text { custom hardware system }\end{array}$ & Verification & Formal Verification & $\begin{array}{c}\text { Mathematical Based } \\
\text { Method }\end{array}$ \\
\hline $\begin{array}{l}\text { (Hammett, Wahl } \\
\text { and Baron, 1999) }\end{array}$ & & & & $x$ & $\begin{array}{l}\text { Measuring the process } \\
\text { capability }\end{array}$ & Both & $\begin{array}{l}\text { Process Capability } \\
\text { Analysis Cp, Cpk }\end{array}$ & Numerical Analysis \\
\hline
\end{tabular}




\begin{tabular}{|c|c|c|c|c|c|c|c|c|c|}
\hline & & & & $x$ & & $\begin{array}{l}\text { Identification of the } \\
\text { optimal tolerances for } \\
\text { flexible validation of the } \\
\text { assembly }\end{array}$ & Both & Tolerance Analysis & Numerical Analysis \\
\hline & & & & $x$ & $x$ & $\begin{array}{l}\text { Creation of a realistic } \\
\text { validation process for } \\
\text { complex assemblies }\end{array}$ & Validation & $\begin{array}{c}\text { Process validation } \\
\text { Method }\end{array}$ & Process Validation \\
\hline \multirow{2}{*}{$\begin{array}{l}\text { (Hazra et al., } \\
\text { 2012) }\end{array}$} & & $x$ & $x$ & & & $\begin{array}{l}\text { Integration of FPV with } \\
\text { simulation }\end{array}$ & Both & $\begin{array}{l}\text { Formal Property } \\
\text { Verification (FPV) }\end{array}$ & $\begin{array}{c}\text { Mathematical Based } \\
\text { Method }\end{array}$ \\
\hline & & $x$ & $x$ & & & $\begin{array}{c}\text { Integration of Simulations } \\
\text { with FPV method for } \\
\text { developing a synergistic } \\
\text { approach }\end{array}$ & Both & Simulations & Simulations \\
\hline \multirow{3}{*}{$\begin{array}{l}\text { (Huang and Kong, } \\
\text { 2010) }\end{array}$} & & $x$ & $x$ & & & $\begin{array}{l}\text { Quality improvement for } \\
\text { multistage manufacturing } \\
\text { process by revealing the } \\
\text { causality relationships } \\
\text { between KCCs and KPCs }\end{array}$ & Both & $\begin{array}{l}\text { Stream of Variation } \\
\text { (SOVA) analysis }\end{array}$ & Numerical Analysis \\
\hline & & & $x$ & & & $\begin{array}{c}\text { Process capability analysis } \\
\text { and evaluation }\end{array}$ & Both & $\begin{array}{l}\text { Process Capability } \\
\text { Analysis } \mathrm{Cp}, \mathrm{Cpk}\end{array}$ & Numerical Analysis \\
\hline & $x$ & $x$ & & & & $\begin{array}{l}\text { Minimisation of KPCs } \\
\text { outputs deviation }\end{array}$ & Both & Taguchi's Method & $\begin{array}{c}\text { Systematic Optimisation } \\
\text { Techniques }\end{array}$ \\
\hline $\begin{array}{l}\text { (Jack Feng and } \\
\text { Wang, 2004) }\end{array}$ & & & $x$ & & & $\begin{array}{l}\text { Study the effectiveness of } \\
\text { each prediction model }\end{array}$ & Validation & Hypothesis Testing & Testing \\
\hline
\end{tabular}




\begin{tabular}{|c|c|c|c|c|c|c|c|}
\hline & & $x$ & $x$ & $\begin{array}{l}\text { Development of prediction } \\
\text { model of the knurling } \\
\text { process }\end{array}$ & Verification & $\begin{array}{l}\text { Artificial Neural } \\
\text { Network (ANN) }\end{array}$ & Numerical Analysis \\
\hline & & $x$ & $x$ & $\begin{array}{l}\text { Development of prediction } \\
\text { model of the knurling } \\
\text { process }\end{array}$ & Verification & Regression Analysis & Numerical Analysis \\
\hline \multirow{2}{*}{ (Jung et al., 2015) } & & $x$ & & $\begin{array}{l}\text { Evaluation and validation } \\
\text { of the product design }\end{array}$ & Validation & Virtual Testing & Testing \\
\hline & & $x$ & & $\begin{array}{l}\text { Validity check of the } \\
\text { proposed framework }\end{array}$ & Validation & Hypothesis Testing & Testing \\
\hline $\begin{array}{l}\text { (Kang, Rong and } \\
\text { Yang, 2003) }\end{array}$ & & $x$ & & $\begin{array}{l}\text { Verification and } \\
\text { improvement of existing } \\
\text { fixture designs }\end{array}$ & Verification & $\begin{array}{l}\text { Computer-aided } \\
\text { fixture design } \\
\text { verification } \\
\text { (CAFDV) }\end{array}$ & CAD Software \\
\hline $\begin{array}{l}\text { (Keefe et al., } \\
\text { 2010) }\end{array}$ & & $x$ & & $\begin{array}{l}\text { Validation of interactive } \\
\text { designs of medical devices } \\
\text { through Virtual Reality }\end{array}$ & Validation & $\begin{array}{l}\text { Virtual Reality } \\
\text { Simulations }\end{array}$ & $\begin{array}{l}\text { Virtual Reality } \\
\text { Simulations }\end{array}$ \\
\hline \multirow[t]{2}{*}{ (Kim et al., 2015) } & & $x$ & $x$ & $\begin{array}{c}\text { Creation of Web-based } \\
\text { automatic regulation } \\
\text { verification tool }\end{array}$ & Verification & $\begin{array}{l}\text { Knowledge-based } \\
\text { approach }\end{array}$ & Knowledge Sharing \\
\hline & & $x$ & $x$ & $\begin{array}{l}\text { Product Design Verification } \\
\text { against regulations }\end{array}$ & Verification & $\begin{array}{l}\text { Regulations } \\
\text { Verification }\end{array}$ & Regulations \\
\hline \multirow{2}{*}{$\begin{array}{c}\text { (Krishnamurthy et } \\
\text { al., 2000) }\end{array}$} & & & & $\begin{array}{l}\text { Model Checking } \\
\text { verification }\end{array}$ & Verification & Formal verification & $\begin{array}{c}\text { Mathematical Based } \\
\text { Method }\end{array}$ \\
\hline & $x$ & $x$ & & $\begin{array}{l}\text { Combination of traditional } \\
\text { simulation with formal } \\
\text { symbolic manipulation }\end{array}$ & Both & $\begin{array}{l}\text { Symbolic } \\
\text { Simulations }\end{array}$ & Simulations \\
\hline
\end{tabular}




\begin{tabular}{|c|c|c|c|c|c|c|c|c|c|}
\hline $\begin{array}{l}\text { (Kundu, Lerner } \\
\text { and Gupta, 2009) }\end{array}$ & $x$ & $x$ & & & & Properties Verification & Verification & $\begin{array}{l}\text { High level } \\
\text { Verification } \\
\text { Techniques } \\
\end{array}$ & $\begin{array}{c}\text { Mathematical Based } \\
\text { Method }\end{array}$ \\
\hline \multirow{2}{*}{$\begin{array}{l}\text { (Lan, Arteau and } \\
\text { Sirard, 2004) }\end{array}$} & & $x$ & $x$ & & & $\begin{array}{l}\text { Multicomponent assembly } \\
\text { verification of a fall arrest } \\
\text { system }\end{array}$ & Both & $\begin{array}{l}\text { Verification against } \\
\text { Standards }\end{array}$ & Standards \\
\hline & & & $x$ & & & $\begin{array}{l}\text { Performance and dynamic } \\
\text { prototype testing }\end{array}$ & Verification & Prototype Testing & Testing \\
\hline \multirow[t]{2}{*}{ (Lari, 2017) } & & $x$ & $x$ & $x$ & & $\begin{array}{l}\text { Conceptual design of a } \\
\text { modular company-wide } \\
\text { information management } \\
\text { model for ISO } 9001\end{array}$ & Both & $\begin{array}{l}\text { Information } \\
\text { exchange }\end{array}$ & $\begin{array}{l}\text { Information } \\
\text { Management }\end{array}$ \\
\hline & & $x$ & $x$ & $x$ & & $\begin{array}{l}\text { Confirmation of process } \\
\text { conformance for ISO } 9001\end{array}$ & Both & Standards & Standards \\
\hline \multirow{2}{*}{$\begin{array}{l}\text { (Lewis et al., } \\
\text { 2005) }\end{array}$} & & $x$ & $x$ & & & $\begin{array}{l}\text { Test Vehicles for laser } \\
\text { techniques validation }\end{array}$ & Verification & $\begin{array}{l}\text { Laser based } \\
\text { Technique }\end{array}$ & Metrology/ Inspection \\
\hline & & $x$ & $\mathrm{x}$ & & & $\begin{array}{l}\text { Numerical Simulations in } \\
\text { ANSYS environment }\end{array}$ & Verification & $\begin{array}{l}\text { Numerical } \\
\text { Simulations }\end{array}$ & Simulations \\
\hline $\begin{array}{l}\text { (Li and Chang, } \\
\text { 2012) }\end{array}$ & & $x$ & & & $x$ & $\begin{array}{l}\text { Dynamic characteristics } \\
\text { Identification in structures }\end{array}$ & Verification & $\begin{array}{c}\text { Stochastic } \\
\text { Subspace } \\
\text { Identification (SSI) }\end{array}$ & Numerical Analysis \\
\hline \multirow{2}{*}{$\begin{array}{l}\text { (Majeske and } \\
\text { Hammett, 2003) }\end{array}$} & & & $x$ & & & $\begin{array}{l}\text { Discrete measurements } \\
\text { points on the product }\end{array}$ & Verification & $\begin{array}{c}\text { Coordinate } \\
\text { Measuring } \\
\text { Machine (CMM) }\end{array}$ & Metrology/ Inspection \\
\hline & & $x$ & $x$ & & & $\begin{array}{c}\text { Quantitative assessment of } \\
\text { the measurement's system } \\
\text { data validity }\end{array}$ & Validation & $\begin{array}{l}\text { Measurement } \\
\text { System Analysis } \\
\text { (MSA) }\end{array}$ & Process Validation \\
\hline
\end{tabular}




\begin{tabular}{|c|c|c|c|c|c|c|c|c|c|c|}
\hline & & & $x$ & $x$ & & & $\begin{array}{c}\text { Preproduction prototype } \\
\text { assessment for functional } \\
\text { build assemblies }\end{array}$ & Both & $\begin{array}{c}\text { Design of } \\
\text { Experiment (DoE) }\end{array}$ & $\begin{array}{c}\text { Systematic Optimisation } \\
\text { Techniques }\end{array}$ \\
\hline \multirow{2}{*}{$\begin{array}{l}\text { (Maropoulos and } \\
\text { Baker, 2000) }\end{array}$} & & & $x$ & & & & $\begin{array}{l}\text { Development of CAD- } \\
\text { based method for tool } \\
\text { selection \& validation }\end{array}$ & Both & VITool software & CAD Software \\
\hline & & $x$ & $x$ & & & & $\begin{array}{l}\text { Validation of the tools } \\
\text { developed and their } \\
\text { features }\end{array}$ & Both & $\begin{array}{l}\text { New Process } \\
\text { Planning }\end{array}$ & Process Validation \\
\hline \multirow{3}{*}{$\begin{array}{l}\text { (Pignataro, } \\
\text { Lobaccaro and } \\
\text { Zani, 2014) }\end{array}$} & & $\mathrm{x}$ & $x$ & & & & $\begin{array}{c}\text { Structural verification of } \\
\text { the design }\end{array}$ & Both & $\begin{array}{l}\text { Finite Element } \\
\text { Method (FEM) }\end{array}$ & Numerical Analysis \\
\hline & & & $x$ & $x$ & & & $\begin{array}{l}\text { Verification of the } \\
\text { architectural concept }\end{array}$ & Both & Rapid prototyping & Physical Prototyping \\
\hline & & & & $x$ & & & $\begin{array}{l}\text { Experimental verification } \\
\text { of model performance }\end{array}$ & Both & $\begin{array}{l}\text { Experimental } \\
\text { Performance } \\
\text { Testing }\end{array}$ & Testing \\
\hline $\begin{array}{l}\text { (Santini-Bell et } \\
\text { al., 2008) }\end{array}$ & & & $\mathrm{x}$ & & & $x$ & $\begin{array}{l}\text { Structural verification of } \\
\text { existing structure and } \\
\text { parameters estimation for } \\
\text { model update }\end{array}$ & Verification & $\begin{array}{l}\text { Non Destructive } \\
\text { Testing }\end{array}$ & Testing \\
\hline \multirow{2}{*}{$\begin{array}{c}\text { (Sanya and } \\
\text { Shehab, 2015) }\end{array}$} & $x$ & $x$ & $x$ & & & & $\begin{array}{l}\text { Validation of model } \\
\text { ontologies by experts }\end{array}$ & Both & Workshop & $\begin{array}{l}\text { Information } \\
\text { Management }\end{array}$ \\
\hline & $x$ & $x$ & $x$ & & & & $\begin{array}{l}\text { Knowledge sharing for } \\
\text { modular design }\end{array}$ & Both & Experts opinion & Knowledge Sharing \\
\hline $\begin{array}{c}\text { (Shehab et al., } \\
\text { 2013) }\end{array}$ & $x$ & $x$ & $x$ & $x$ & $x$ & & $\begin{array}{c}\text { Information capturing the } \\
\text { AS-IS situation }\end{array}$ & Both & $\begin{array}{l}\text { Semi-structured } \\
\text { interviews }\end{array}$ & $\begin{array}{l}\text { Information } \\
\text { Management }\end{array}$ \\
\hline
\end{tabular}




\begin{tabular}{|c|c|c|c|c|c|c|c|c|c|}
\hline & $\mathrm{x}$ & $x$ & $x$ & $x$ & $x$ & $\begin{array}{l}\text { Validation of solution } \\
\text { requirements and the } \\
\text { developed scenarios }\end{array}$ & Validation & Workshop & Knowledge Sharing \\
\hline \multirow{2}{*}{$\begin{array}{c}\text { (Shen and } \\
\text { Abraham, 2000) }\end{array}$} & & $x$ & $\mathrm{x}$ & & & $\begin{array}{l}\text { Development of formal } \\
\text { reasoning scenarios }\end{array}$ & Both & Formal verification & $\begin{array}{c}\text { Mathematical Based } \\
\text { Method }\end{array}$ \\
\hline & & $x$ & $x$ & & & $\begin{array}{l}\text { Validation of the product's } \\
\text { design }\end{array}$ & Validation & $\begin{array}{l}\text { Symbolic } \\
\text { Simulations }\end{array}$ & Simulations \\
\hline \multirow[t]{2}{*}{$\begin{array}{l}\text { (Sibois et al., } \\
\text { 2014) }\end{array}$} & $x$ & $\mathrm{x}$ & $x$ & & & $\begin{array}{l}\text { Managing simulations in } \\
\text { collaboration with the PLM }\end{array}$ & Both & $\begin{array}{l}\text { Simulation } \\
\text { Lifecycle } \\
\text { Management } \\
\text { (SLM) }\end{array}$ & Simulations \\
\hline & & $\mathrm{x}$ & $x$ & $x$ & & $\begin{array}{l}\text { Validation of system's } \\
\text { requirements }\end{array}$ & Both & $\begin{array}{l}\text { Digital Mock Up } \\
\text { (DMU) }\end{array}$ & Digital Prototyping \\
\hline \multirow{3}{*}{$\begin{array}{l}\text { (Stark, Kind and } \\
\text { Neumeyer, 2017) }\end{array}$} & & & $x$ & & & $\begin{array}{l}\text { Creation \& validation of } \\
\text { optimum Cyber Physical } \\
\text { Production Systems (CPPS) } \\
\text { architecture }\end{array}$ & Both & Virtual prototyping & Digital Prototyping \\
\hline & & $x$ & $x$ & & & $\begin{array}{c}\text { Use of VR for assembly } \\
\text { validation }\end{array}$ & Validation & Virtual Assembly & $\begin{array}{l}\text { Virtual Reality } \\
\text { Simulations }\end{array}$ \\
\hline & & $x$ & $x$ & & & $\begin{array}{c}\text { Behaviour modelling } \\
\text { extended by skill } \\
\text { negotiation and execution }\end{array}$ & Validation & Simulation & $\begin{array}{l}\text { Virtual Reality } \\
\text { Simulations }\end{array}$ \\
\hline $\begin{array}{c}\text { (Suresh, Ozev and } \\
\text { Sinanoglu, 2015) }\end{array}$ & & & $x$ & & & $\begin{array}{l}\text { Use of software simulation } \\
\text { for validation of the } \\
\text { proposed ID generation } \\
\text { method }\end{array}$ & Validation & Simulation Method & Simulations \\
\hline
\end{tabular}




\begin{tabular}{|c|c|c|c|c|c|c|c|c|c|}
\hline & & & & $x$ & & $\begin{array}{l}\text { Generation of unique ID } \\
\text { for product genuinity } \\
\text { identification across the } \\
\text { Supply Chain }\end{array}$ & Both & $\begin{array}{c}\text { Identification } \\
\text { generation Method }\end{array}$ & $\begin{array}{c}\text { Tracking } \\
\text { Methods/Identification } \\
\text { Methods }\end{array}$ \\
\hline $\begin{array}{l}\text { (Urbanic and } \\
\text { Elmaraghy, 2009) }\end{array}$ & $x$ & $x$ & $x$ & & & $\begin{array}{l}\text { Potential problem } \\
\text { diagnosis based on target } \\
\text { tolerance variations }\end{array}$ & Validation & $\begin{array}{l}\text { Matrix based } \\
\text { modified Failure } \\
\text { Mode \& Effect } \\
\text { Analysis (FMEA) }\end{array}$ & $\begin{array}{c}\text { Product Requirements/ } \\
\text { Development }\end{array}$ \\
\hline \multirow{3}{*}{$\begin{array}{l}\text { (Vyatkin et al., } \\
\text { 2009) }\end{array}$} & & $x$ & $x$ & & & $\begin{array}{c}\text { Testing the system's } \\
\text { correctness }\end{array}$ & Validation & Formal Validation & $\begin{array}{c}\text { Mathematical Based } \\
\text { Method }\end{array}$ \\
\hline & & $x$ & $x$ & & & $\begin{array}{l}\text { Support the Formal V\&V } \\
\text { methods and achieve } \\
\text { automated validation }\end{array}$ & & $\begin{array}{c}\text { Unified Modelling } \\
\text { Language (UML) \& } \\
\text { net condition event } \\
\text { systems }\end{array}$ & $\begin{array}{c}\text { Mathematical Based } \\
\text { Method }\end{array}$ \\
\hline & & $x$ & $x$ & & & $\begin{array}{l}\text { Use of Simulink to aid } \\
\text { Formal V\&V methods }\end{array}$ & Both & Simulations & Simulations \\
\hline \multirow{3}{*}{$\begin{array}{c}\text { (Wakabayashi et } \\
\text { al., 2017) }\end{array}$} & & & & $x$ & $x$ & $\begin{array}{c}\text { Data Management System } \\
\text { validation }\end{array}$ & Both & Cloud Computing & $\begin{array}{l}\text { Information } \\
\text { Management }\end{array}$ \\
\hline & & & & $x$ & $\mathrm{x}$ & $\begin{array}{l}\text { Collect data for } \\
\text { Verification processes }\end{array}$ & Verification & Smart devices & $\begin{array}{c}\text { Tracking } \\
\text { Methods/Identification } \\
\text { Methods }\end{array}$ \\
\hline & & & & & $x$ & Supplier's data validation & Both & $\begin{array}{c}\text { Tracking / } \\
\text { documentation }\end{array}$ & $\begin{array}{c}\text { Tracking } \\
\text { Methods/Identification } \\
\text { Methods }\end{array}$ \\
\hline
\end{tabular}




\begin{tabular}{|c|c|c|c|c|c|c|c|c|}
\hline $\begin{array}{l}\text { (Weissman, } \\
\text { Petrov and } \\
\text { Gupta, 2011) }\end{array}$ & $x$ & $x$ & & & $\begin{array}{l}\text { Standardisation of writing } \\
\text { Product Design } \\
\text { Specification (PDS) and } \\
\text { relevant information for } \\
\text { automated V\&V }\end{array}$ & Both & $\begin{array}{l}\text { Computational \& } \\
\text { Software Tool }\end{array}$ & $\begin{array}{l}\text { Information } \\
\text { Management }\end{array}$ \\
\hline $\begin{array}{l}\text { (Witherell et al., } \\
\text { 2010) }\end{array}$ & & $x$ & & & $\begin{array}{l}\text { To provide a structured } \\
\text { approach for enhancing } \\
\text { knowledge sharing } \\
\text { acquisition and knowledge } \\
\text { validation techniques in } \\
\text { engineering design } \\
\text { ontologies }\end{array}$ & Both & $\begin{array}{l}\text { Logic-based } \\
\text { method }\end{array}$ & Knowledge Sharing \\
\hline \multirow[t]{2}{*}{$\begin{array}{l}\text { (Wöhlke and } \\
\text { Schiller, 2005) }\end{array}$} & & $x$ & $x$ & & $\begin{array}{l}\text { Use of Digital Mock-Up } \\
\text { (DMU) and simulations for } \\
\text { checking the planning } \\
\text { state of the digital product }\end{array}$ & Validation & $\begin{array}{l}\text { Digital Planning } \\
\text { Validation (DPV) }\end{array}$ & Process Validation \\
\hline & & $x$ & $x$ & & $\begin{array}{l}\text { Validation of the digital } \\
\text { product }\end{array}$ & Validation & $\begin{array}{l}\text { Digital Mock Up } \\
\text { (DMU) }\end{array}$ & Digital Prototyping \\
\hline \multirow{2}{*}{ (Yan et al., 2008) } & & $x$ & $x$ & & $\begin{array}{c}\text { Testing/ calibration of } \\
\text { subscale compressor } \\
\text { models }\end{array}$ & Both & $\begin{array}{l}\text { Experimental } \\
\text { Validation }\end{array}$ & Testing \\
\hline & & $x$ & $x$ & $\mathrm{x}$ & $\begin{array}{c}\text { Achieve validation and gain } \\
\text { insight on product's } \\
\text { behaviour }\end{array}$ & Validation & $\begin{array}{l}\text { Computational } \\
\text { Fluid Dynamics } \\
\text { (CFD) }\end{array}$ & Simulations \\
\hline $\begin{array}{l}\text { (Yang, Vyatkin } \\
\text { and Pang, 2014) }\end{array}$ & & & $x$ & & $\begin{array}{l}\text { Creation of standards for } \\
\text { distributed systems } \\
\text { modelling and validation }\end{array}$ & Both & $\begin{array}{l}\text { Distributed logic } \\
\text { Simulations }\end{array}$ & Simulations \\
\hline
\end{tabular}




\begin{tabular}{|c|c|c|c|c|c|c|c|}
\hline $\begin{array}{c}\text { (Zbrozek et al., } \\
\text { 2013) }\end{array}$ & $\mathrm{x}$ & $x$ & $\mathrm{x}$ & $\begin{array}{l}\text { Guidance on how to } \\
\text { achieve validation of the } \\
\text { requirements of a data } \\
\text { collection device }\end{array}$ & Validation & $\begin{array}{c}\text { Process Validation } \\
\text { Method }\end{array}$ & Process Validation \\
\hline
\end{tabular}




\section{Authors' Biographies}

Aineias Karkasinas is a $\mathrm{PhD}$ researcher in Engineering Management at the University of Strathclyde, Department of Design, Manufacture and Engineering Management. He holds a Bachelor in Mechanical Engineering and a master's in industrial management \& Operational Research. He is currently completing his $\mathrm{PhD}$ in 'Product Verification and Validation for SMEs'. His interest focuses on Industrial Management, Quality Management, Circular Economy and decision making.

Contact: aineias.karkasinas@strath.ac.uk

Athanasios Rentizelas is a Lecturer in Engineering Management at the University of Strathclyde, Department of Design, Manufacture and Engineering Management. Dr Rentizela's research interests lie in Supply networks \& Reverse supply chain design and optimization; Sustainability assessment and performance improvement in extended supply chains; Digitally enabled supply chains; Quality Management; Energy-related supply chains, such as the unconventional Oil \& Gas and Bio-based value chains. He has led or participated in more than 20 research \& consultancy projects during the past 15 years and has published 26 articles in peer-reviewed international journals and four book chapters in the relevant fields.

Contact: athanasios.rentizelas@strath.ac.uk

\section{Corresponding author}

Aineias Karkasinas can be contacted at: aineias.karkasinas@strath.ac.uk 